\title{
In silico and gene expression analysis of the acute inflammatory response of gilthead seabream (Sparus aurata) after subcutaneous administration of carrageenin
}

\author{
Jose Carlos Campos-Sánchez • \\ Javier Mayor-Lafuente $\cdot$ Francisco A. Guardiola • \\ María Ángeles Esteban (1)
}

Received: 5 March 2021 / Accepted: 8 August 2021

(C) The Author(s) 2021

\begin{abstract}
Inflammation is one of the main causes of loss of homeostasis at both the systemic and molecular levels. The aim of this study was to investigate in silico the conservation of inflammation-related proteins in the gilthead seabream (Sparus aurata L.). Open reading frames of the selected genes were used as input in the STRING database for protein-protein interaction network analysis, comparing them with other teleost protein sequences. Proteins of the large yellow croaker (Larimichthys crocea L.) presented the highest percentages of identity with the gilthead seabream protein sequence. The gene expression profile of these proteins was then studied in gilthead seabream specimens subcutaneously injected with carrageenin $(1 \%)$ or phosphate-buffered saline (control) by analyzing skin samples from the injected zone 12 and $24 \mathrm{~h}$ after injection. Gene expression analysis indicated that the mechanisms necessary to terminate the inflammatory response to carrageenin and recover skin homeostasis were activated between 12 and $24 \mathrm{~h}$ after injection (at the tested dose). The gene analysis performed in this study could contribute to the identification of the main mechanisms of acute
\end{abstract}

J. C. Campos-Sánchez · J. Mayor-Lafuente ·

F. A. Guardiola · M. Á. Esteban ( $₫)$

Immunobiology for Aquaculture Group, Department

of Cell Biology and Histology, Faculty of Biology,

University of Murcia, Campus Regional de Excelencia

Internacional "Campus Mare Nostrum”, 30100 Murcia,

Spain

e-mail: aesteban@um.es inflammatory response and validate the use of carrageenin as an inflammation model to elucidate these mechanisms in fish.

Keywords Carrageenin - Skin inflammation · In silico analysis · Gene expression · Teleosts · Aquaculture

\section{Introduction}

Inflammation is a temporary local response characterized by heat, redness, swelling, pain, and functional disorders (Nathan 2002). It is triggered by the innate immune system to protect the host against tissue damage, and its aim is to restore physiological functions when homeostatic mechanisms are insufficient (Medzhitov 2008). Inflammation consists of a sequence of events. Depending on diverse factors (such as the causal agent of the inflammation or the anatomical site where it is triggered), inflammatory mediators (including prostaglandins, histamines, cytokines, reactive oxygen species, and enzymes) are released by tissue-resident immune and non-immune cells to increase the blood flow and cause vasodilation (Calder et al. 2013). Capillary permeability is subsequently increased due to the retraction of endothelial cells, allowing access of many large and soluble molecules to the inflammation site (Calder et al. 2013). The third main event is the recruitment of leucocytes (granulocytes, neutrophils, eosinophils 
and basophils, and monocytes-macrophages) from the blood capillaries to the surrounding tissues and subsequently to the inflammation site due to the repertoire of chemokines and adhesion molecules released by endothelial cells (Calder et al. 2013). Finally, inhibitory mechanisms are normally activated to terminate the inflammatory process and initiate the repair of damaged tissue (Calder et al. 2013), thus preventing unnecessary damage and restoring homeostasis (Chen and Nuñez 2010; Henson 2005). However, if these mechanisms fail to restore homeostasis, inflammation may persist, resulting in a pathological state of chronic inflammation and even chronic diseases (Nathan and Ding 2010; Serhan et al. 2011).

Although inflammatory processes have been extensively studied in mammals, they have not been sufficiently studied in fish. The intensive fish production in aquaculture, one of the fastestgrowing sectors in the world in the past few decades, is very frequently associated with inflammation caused injuries, especially wounds and ulcers in the skin of farmed fish (Chen and Nuñez 2010). Moreover, fish are highly susceptible to stress due to the intimate contact with their environment, which can compromise their welfare and promote illness (Delamare-Deboutteville et al. 2006). The final consequences of inflammation and the outbreak of diseases in fish are substantial economic losses (Balcázar et al. 2006; Esteban 2012). Therefore, the search and use of non-invasive methods, such as in silico analyses, can be beneficial for the study of molecular processes that have scarcely been studied in fish, such as inflammation (Liu et al. 2014; Romano and Tatonetti 2019). Exploring the conservation of pro-inflammatory and antiinflammatory proteins and other inflammationrelated molecules among species, as well as their functions, could contribute to the identification of the patterns and signal transduction pathways that regulate this complex process (Hawiger and Zienkiewicz 2019). Since physical interactions between proteins play an important role in this process, study methods are increasingly based on predicting protein-protein interactions purely from protein sequences to identify proteins that have not been previously studied (Makrodimitris et al. 2020). The public online database Search Tool for the Retrieval of Interacting Genes and Proteins (STRING; https://string-db.org/) provides accurate information on protein associations (interactions) by combining different sources and techniques, such as gene co-expression and text mining, and can assign a protein interaction probability score to each physical interaction and functional association (Szklarczyk et al. 2019). These scores have been used to reconstruct protein-protein interaction networks (Kummer et al. 2018). However, the complexity of the studied organisms and the information extracted from the database may vary to such a degree that a protein interaction may not coincide with the organism of interest or may not offer contextual information, necessitating experimental validation of the obtained results (Björne and Salakoski 2019).

In this study, we used carrageenin to better understand the mechanism of inflammation. Carrageenin is a high-molecular-weight sulfated mucopolysaccharide derived from the cell wall of the red algae commonly called Irish moss or carrageen moss (Chondrus crispus). It has been used for decades as a model of acute inflammation in rats, mice, and guinea pigs and in in vitro inflammation experiments in humans (Bhattacharyya et al. 2008a, b; Bhattacharyyaa et al. 2010; Levy 1969; Morris 2003; Winter et al. 1962). Carrageenin is composed of $1,3 \alpha-1,4 \beta$-galactans having one ( $\kappa-)$, two (1-), or three $(\lambda-)$ sulfates per disaccharide unit and can produce an inflammatory response associated with edema, hyperalgesia, and erythema and an acute response to thermal and mechanical stimuli. When self-associating into helical structures, $\kappa$ - and 1 -carrageenin can form rigid and flexible gels, respectively, in ionic solutions and seems to be related to the immunostimulant activity against bacterial infections in teleost fish (Cheng et al. 2007; Fujiki et al. 1994, 1997; Necas and Bartosikova 2013). In contrast, $\lambda$-carrageenin does not form helices or gels, but it is the main compound responsible for inducing an acute inflammation response when injected in rodents (Fujiki et al. 1997). The few studies investigating the effects of carrageenin on fish have reported that intraperitoneal injection of carrageenin induces acute inflammation characterized by leucocyte infiltration and significant abdominal edema a few hours after administration, peaking several hours later (Huang et al. 2014; Martins et al. 2006; Matushima and Mariano 1996; Ribas et al. 2016). After being injected, carrageenin seems to remain extracellularly for several hours, causing chronic inflammation until macrophages begin to 
engulf and store it in cytoplasmic vesicles, eventually removing all the extracellular carrageenin by the end of the inflammation process (Timur et al. 1977).

In light of these findings, the aim of this study was to evaluate the involvement of 40 inflammationrelated proteins (cellular markers and proinflammatory and anti-inflammatory proteins) in the inflammatory process evoked by the subcutaneous administration of carrageenin. Carrageenin was selected because it is known to trigger inflammation in mammals (Levy 1969; Winter et al. 1962; Morris 2003), while the gilthead seabream was chosen as a fish species of interest to marine aquaculture (APROMAR 2019). STRING was used to compare the protein sequence of the genes studied in gilthead seabreams with protein sequences in other similar fish species. The functional associations and interactions between the proteins involved in the same process and their level of conservation were also studied. To our knowledge, this is the first study to evaluate the modulation of gene expression after carrageenin administration in fish.

\section{Materials and methods}

Protein prediction and functional protein association network analysis

Based on previous inflammation studies on mammals and zebrafish (Campos-Sánchez and Esteban 2021; Chen and Nuñez 2010) and taking into account the published gilthead seabream genome, 40 inflammation-related proteins were selected to investigate the conservation of inflammatory routes. These proteins were divided into three groups: (i) cell marker proteins (colony-stimulating factor 1 receptor [CSF1R], NADPH oxidase subunit Phox22 [PHOX22], NADPH oxidase subunit Phox40 [PHOX40], and major histocompatibility complex class IIa [MHCII]), (ii) pro-inflammatory proteins (interleukin-1 $\beta$ [IL-1 $\beta]$, tumor necrosis factor alpha [TNF- $\alpha$ ], interleukin-6 [IL-6], interleukin-7 [IL-7], interleukin-8 [IL-8], interleukin-18 [IL-18], toll-like receptor 2 [TLR2], toll-like receptor 5 [TLR5], toll-like receptor 7 [TLR7], toll-like receptor 8 [TLR8], toll-like receptor 9 [TLR9], toll-like receptor 13 [TLR13], v-rel avian reticuloendotheliosis viral oncogene homolog
A [RelA], v-rel avian reticuloendotheliosis viral oncogene homolog [C-Rel], v-rel avian reticuloendotheliosis viral oncogene homolog B [RelB], nuclear factor of kappa light polypeptide gene enhancer in B-cells 1 [NF- $\mathrm{KB} 1]$, nuclear factor of kappa light polypeptide gene enhancer in B-cells 2 [NF- $\mathrm{KB} 2$ ], tumor necrosis factor receptor superfamily, member 1a [TNFRSFa], tumor necrosis factor receptor superfamily, member 1b [TNFRSF1b], TNF receptor-associated factor 6 [TRAF6], interleukin-1 receptor-associated kinase 1 [IRAK1], inhibitor of nuclear factor kappa B kinase regulatory subunit gamma [IKBKG], MYD88 innate immune signal transduction adaptor [MYD88], and signal transducer and activator of transcription 3 [STAT3]), and (iii) anti-inflammatory proteins (interleukin-10 [IL-10], transforming growth factor beta 1 [TGF- $\beta 1$ ], cathepsin D [CTSD], cathepsin L [CTSL], cathepsin S [CTSS], NLR family CARD domain containing 3 [NLRC3], NLR family, NLR family CARD domain containing 5 [NLRC5 isoforms 1 and 2], NLR family member X1 [NLRX1], acetylcholinesterase $[\mathrm{AChE}]$, butyrylcholinesterase [BChE], and cholinergic receptor nicotinic alpha 7 [nAChR $\alpha 7])$.

The gene sequences of the selected proteins were obtained from the gilthead seabream database using the whole-genome shotgun method (Pareek et al. 2011). The open reading frames of such genes were located using the ORFfinder software from the NCBI website (https://www.ncbi.nlm.nih.gov/orffi nder/), and an additional check was performed using NCBI Protein BLAST sequence alignment analysis (National Institutes of Health). The protein sequences obtained were used as input in the STRING database for the protein-protein interaction network functional enrichment analysis, comparing sequences between teleosts (superclass Actinopterygii). The percentages of identity of the most similar proteins and the $e$-values were used to investigate the conservation and interactions of gilthead seabream proteins. The protein names were derived automatically based on a cluster's consensus protein annotations taken from Gene Ontology (GO), the Kyoto Encyclopedia of Genes and Genomes (KEGG), Reactome (2021), UniProt, Pfam, Simple Modular Architecture Research Tool (SMART), and InterPro. The predicted orthologous proteins were associated in networks, where nodes (proteins) and edges (protein-protein associations) denoted the number of predicted interactions 
between them compared to interactions that would be expected for a random set of proteins of a similar size.

\section{Design of the primers}

The primers used were designed with the Thermo Fisher OligoPerfect ${ }^{\mathrm{TM}}$ tool according to the following criteria: (i) each oligonucleotide was composed of 20 nucleotides, (ii) the size of the amplicon had between 100 and 120 nucleotides, (iii) the guanidine-cytosine content was 55-60\%, (iv) the semi-naturalization temperature (melting temperature) was as close to $60{ }^{\circ} \mathrm{C}$ as possible, and (v) primers that self-inhibit and form hairpins were avoided so as not to hinder the amplification reaction (Table 1).

Animals

Sixteen specimens $(23.7 \pm 7 \mathrm{~g}$ in weight and $11.7 \pm 1 \mathrm{~cm}$ in length) of the seawater teleost gilthead seabream, obtained from a local farm (Mazarrón, Spain), were kept in recirculating seawater aquaria $(250 \mathrm{~L})$ in the Marine Fish Facilities of the University of Murcia (Spain) for a quarantine period of 1 month. The water temperature was maintained at $20 \pm 2{ }^{\circ} \mathrm{C}$ with a flow rate of $900 \mathrm{~L} \mathrm{~h}^{-1}, 28 \%$ salinity, and a 12-h light and 12-h dark photoperiod. The water in the tanks was continuously aerated. The fish were fed a commercial diet (Perla MP, Skretting) in quantities amounting to $2 \%$ of their body weight daily and were subjected to 24 -h fasting before the experiment. Commercial diet consisted of crude protein $(48.5 \%)$, crude oils and fats (18\%), crude ash $(6.8 \%)$, crude fiber $(2.2 \%)$, phosphorus $(0.9 \%)$, calcium $(0.9 \%)$, and sodium $(0.3 \%)$. All experimental protocols were conformed to Directive 2010/63/EU and approved by the Ethics Committee of the University of Murcia.

Experimental design and sample collection

The fish were anesthetized with clove oil $(20 \mathrm{mg}$ $\mathrm{L}^{-1}$; Guinama), and subcutaneously injected in their left flank, in the middle part between the lateral line and the central zone of the anal fin. Two groups with two replicates $(n=4)$ were randomly established: (i) fish injected with $50 \mu \mathrm{l}$ of phosphate-buffered saline (PBS; $11.9 \mathrm{mM}$ phosphates, $137 \mathrm{mM} \mathrm{NaCl}$, and $2.7 \mathrm{mM} \mathrm{KCl}$; pH 7.4; Fisher Bioreagents) (control group) and (ii) fish injected with $50 \mu \mathrm{l}$ of carrageenin in PBS (1\%; Sigma-Aldrich) (carrageenin group). Twelve and $24 \mathrm{~h}$ after injection, two fish from each tank were randomly caught and sedated as previously described. Skin from the injected area was collected with a biopsy metal punch $4 \mathrm{~mm}$ in diameter (Stiefel). The skin samples were immediately stored in TRIzol Reagent (Invitrogen) at $-80{ }^{\circ} \mathrm{C}$ for gene expression analysis (Chomczynski 1993).

Gene expression analysis by real-time qPCR

Total RNA was extracted from $0.5 \mathrm{~g}$ samples of gilthead seabream skin using TRIzol, following the manufacturer's instructions, and quantification and purification were assessed using a Nanodrop ${ }^{\circledR}$ spectrophotometer (the 260:280 ratios were 1.8-2.0). Then, the RNA was treated with DNase I (Promega) to remove genomic DNA contamination and complementary DNA (cDNA) was synthesized from $1 \mu \mathrm{g}$ of RNA using the reverse transcriptase enzyme SuperScriptIV (Life Technologies) with an oligo$\mathrm{dT}_{18}$ primer. The expression of the nominated genes (see Table 1) was analyzed by real-time qPCR with QuantStudio $^{\mathrm{TM}}$ Real-Time PCR System Fast (Life Technologies). The reaction mixtures [containing $5 \mu \mathrm{l}$ of SYBR Green supermix, $2.5 \mu \mathrm{l}$ of primers $(0.6 \mu \mathrm{M}$ each), and $2.5 \mu \mathrm{l}$ of cDNA template] were incubated for $10 \mathrm{~min}$ at $95{ }^{\circ} \mathrm{C}$, followed by 40 cycles of $15 \mathrm{~s}$ at $95{ }^{\circ} \mathrm{C}, 1 \mathrm{~min}$ at $60{ }^{\circ} \mathrm{C}$, and finally $15 \mathrm{~s}$ at $95{ }^{\circ} \mathrm{C}$, $1 \mathrm{~min}$ at $60{ }^{\circ} \mathrm{C}$, and $15 \mathrm{~s}$ at $95{ }^{\circ} \mathrm{C}$. The gene expression was analyzed using the $2^{-\Delta \mathrm{Ct}}$ method (Livak and Schmittgen 2001), which was performed as described elsewhere (Cordero et al. 2015). The specificity of the reactions was analyzed using samples without cDNA as negative controls. For each mRNA, gene expression was normalized with the geometric mean of ribosomal protein $(s 18)$, elongation factor 1-alfa $(e f l \alpha$ ), and beta-actin (actb) RNA content in each sample. Gene names follow the accepted nomenclature for zebrafish (http://zfin.org/). In all cases, each PCR was performed with triplicate samples.

\section{Statistical analysis}

The results were expressed as mean \pm standard error of the mean (SEM). Data were analyzed by two-way ANOVA (followed by Tukey tests) to determine differences between experimental groups and each group with respect to time. The normality of the data 
Table 1 Primers used for real-time qPCR

\begin{tabular}{|c|c|c|c|c|}
\hline Gene name & Gene abbreviation & GenBank number & Primer sequences $\left(5^{\prime} \rightarrow 3^{\prime}\right)$ & $\begin{array}{l}\text { Primer efficien- } \\
\text { cies }\end{array}$ \\
\hline NADPH oxidase, subunit Phox 40 & phox40 & AM749961 & $\begin{array}{l}\text { F: GCGGAGTTGAACCTGAAGAG } \\
\text { R: TCACCTTCTGTGTCGCTGTC }\end{array}$ & $106.37 \%$ \\
\hline $\begin{array}{l}\text { Colony-stimulating factor receptor } \\
1\end{array}$ & csfrl & AM050293 & $\begin{array}{l}\text { F: ACGTCTGGTCCTATGGCATC } \\
\text { R: AGTCTGGTTGGGACATCTGG }\end{array}$ & $91.53 \%$ \\
\hline NADPH oxidase, subunit Phox22 & phox 22 & FM148169 & $\begin{array}{l}\text { F: CATCAAGAATCCCCCTCAGA } \\
\text { R: TGACAGAGATGGGGTTGTCA }\end{array}$ & $96.26 \%$ \\
\hline $\begin{array}{l}\text { Major histocompatibility complex } \\
\text { class IIa }\end{array}$ & mhcIIa & DQ019401 & $\begin{array}{l}\text { F: CTGGACCAAGAACGGAAAGA } \\
\text { R: CATCCCAGATCCTGGTCAGT }\end{array}$ & $114.95 \%$ \\
\hline $\begin{array}{l}\text { Nuclear factor of kappa light } \\
\text { polypeptide gene enhancer in } \\
\text { B-cells } 2\end{array}$ & $n f k b 2$ & B012900 & $\begin{array}{l}\text { F: ATCACAGCGCAGAGATCGAG } \\
\text { R: TGCGGGATGTAGGTGAACTG }\end{array}$ & $94.67 \%$ \\
\hline $\begin{array}{l}\text { Signal transducer and activator of } \\
\text { transcription } 3\end{array}$ & stat3 & B015325 & $\begin{array}{l}\text { ACATCCTTGGCACCAACACA } \\
\text { ACCATTGCCACACCTCTGTT }\end{array}$ & $97.10 \%$ \\
\hline TNF receptor-associated factor 6 & traf6 & B010645 & $\begin{array}{l}\text { ACCTGTGTCGTGCCAAGATT } \\
\text { TCACAGTACTGGCACGTCAC }\end{array}$ & $96.84 \%$ \\
\hline Toll-like receptor 2 & $\operatorname{tl} 2$ & B008611 & $\begin{array}{l}\text { F: TCCATGCTTTCGTCCAGGAC } \\
\text { R: ACTGTGTTGAGCAAGGCCTC }\end{array}$ & $95.94 \%$ \\
\hline Tumor necrosis factor alpha & $\operatorname{tnf}-\alpha$ & AJ413189 & $\begin{array}{l}\text { F: CTGTGGAGGGAAGAATCGAG } \\
\text { R: TCCACTCCACCTGGTCTTTC }\end{array}$ & $112.93 \%$ \\
\hline $\begin{array}{l}\text { Inhibitor of nuclear factor kappa B } \\
\text { kinase regulatory subunit gamma }\end{array}$ & $i k b k g$ & В006470 & $\begin{array}{l}\text { GAAGGAGGAGGTGGAGCAAC } \\
\text { СТСТСTCGСTTCTCGСTCTG }\end{array}$ & $104.24 \%$ \\
\hline $\begin{array}{l}\text { MYD88 innate immune signal } \\
\text { transduction adaptor }\end{array}$ & myd 88 & B013233 & $\begin{array}{l}\text { GCCTTCATCTGCTACTGCCA } \\
\text { TCTGTCGAACACGCACAGTT }\end{array}$ & $100.69 \%$ \\
\hline $\begin{array}{l}\text { v-rel avian reticuloendotheliosis } \\
\text { viral oncogene homolog A }\end{array}$ & rela & B030837 & $\begin{array}{l}\text { F: GAACCCCACCCTCATGAGTG } \\
\text { R: GTTCTGGGCAGCAGTAGAGG }\end{array}$ & $109.93 \%$ \\
\hline $\begin{array}{l}\text { Nuclear factor of kappa light } \\
\text { polypeptide gene enhancer in } \\
\text { B-cells } 1\end{array}$ & $n f k b 1$ & B005908 & $\begin{array}{l}\text { F: CCGACAGACGTTCACAGACA } \\
\text { R: TCTTCAGCTGGACGAACACC }\end{array}$ & $98.33 \%$ \\
\hline $\begin{array}{l}\text { v-rel avian reticuloendotheliosis } \\
\text { viral oncogene homolog }\end{array}$ & rel & B018958 & $\begin{array}{l}\text { F: AAGCAAGAGCCCCAGATCAC } \\
\text { R: TAGGGCGAGGAAGCAAGTTG }\end{array}$ & $104.50 \%$ \\
\hline $\begin{array}{l}\text { v-rel avian reticuloendotheliosis } \\
\text { viral oncogene homolog B }\end{array}$ & relb & B012502 & $\begin{array}{l}\text { F: ACAGAGGAGGTGGAGGTCAG } \\
\text { R: TATGGATCTGGGTTGTGCGG }\end{array}$ & $106.97 \%$ \\
\hline $\begin{array}{l}\text { Tumor necrosis factor receptor } \\
\text { superfamily, member } 1 \mathrm{a}\end{array}$ & tnfrsfla & B006439 & $\begin{array}{l}\text { F: TCTTGCGTCTGCTCTCAGTG } \\
\text { R: CCTCAGCATCTGGTACTGCC }\end{array}$ & $96.18 \%$ \\
\hline Toll-like receptor 5 & $\operatorname{tlr} 5$ & B001824 & $\begin{array}{l}\text { F: CAACTTGAGCTCCAACGCAC } \\
\text { R: GGCTGGAGATAGGTCAAGGC }\end{array}$ & $95.54 \%$ \\
\hline Toll-like receptor 7 & $t l r 7$ & B004477 & $\begin{array}{l}\text { F: CCAACAATGGGAGCATGGTG } \\
\text { R: ATGGTGAGAGTCAGGTTG } \\
\text { GTG }\end{array}$ & $104.10 \%$ \\
\hline
\end{tabular}


Table 1 (continued)

\begin{tabular}{|c|c|c|c|c|}
\hline Gene name & Gene abbreviation & GenBank number & Primer sequences $\left(5^{\prime} \rightarrow 3^{\prime}\right)$ & $\begin{array}{l}\text { Primer efficien- } \\
\text { cies }\end{array}$ \\
\hline $\begin{array}{l}\text { Interleukin-1 receptor-associated } \\
\text { kinase } 1\end{array}$ & irakl & B011814 & $\begin{array}{l}\text { TGGTGCTGCTGGAGATTCTG } \\
\text { AACCGTTCGGACTTTCCTCC }\end{array}$ & $96.39 \%$ \\
\hline Toll-like receptor 8 & $\operatorname{tlr} 8$ & B024796 & $\begin{array}{l}\text { F: CCAGAGCAATTCCAGGGCTA } \\
\text { R: TGTCCAGCCCTTTGAACTCTG }\end{array}$ & $90.43 \%$ \\
\hline Interleukin-1 & $i l-1 \beta$ & AJ277166 & $\begin{array}{l}\text { F: GCGAGCAGAGGCACTTAGTC } \\
\text { R: GGTAGGTCGCCATGTTCAGT }\end{array}$ & $103.50 \%$ \\
\hline Toll-like receptor 13 & $\operatorname{tlr} 13$ & B003345 & $\begin{array}{l}\text { F: CCTCCCTGCCTTGACGTATC } \\
\text { R: TGTCTGGTTGTTGCTCTGCA }\end{array}$ & $112.59 \%$ \\
\hline $\begin{array}{l}\text { Tumor necrosis factor receptor } \\
\text { superfamily, member } 1 \mathrm{~b}\end{array}$ & tnfrsflb & B026296 & $\begin{array}{l}\text { F: TACCGCAGCTCTTCACGATC } \\
\text { R: ACTGTGTGGGGATGCTGATC }\end{array}$ & $98.91 \%$ \\
\hline Interleukin-7 & $i l-7$ & JX976618 & $\begin{array}{l}\text { F: GATCTGGAAAACACCGGAGA } \\
\text { R: TGGACGTGCGTTCTGGTAGC }\end{array}$ & $98.85 \%$ \\
\hline Interleukin-18 & il-18 & JX976626 & $\begin{array}{l}\text { F: TTGAGGGGTTGTCCTGTTTC } \\
\text { R: AGTTTTTACCCCAGCCCTGT }\end{array}$ & $90.32 \%$ \\
\hline Interleukin-6 & $i l-6$ & AM749958 & $\begin{array}{l}\text { F: AGGCAGGAGTTTGAAGCTGA } \\
\text { R: ATGCTGAAGTTGGTGGAAGG }\end{array}$ & $96.80 \%$ \\
\hline Interleukin-8 & $i l-8$ & AM765841 & $\begin{array}{l}\text { F: GCCACTCTGAAGAGGACAGG } \\
\text { R: TTTGGTTGTCTTTGGTCGAA }\end{array}$ & $105.99 \%$ \\
\hline Toll-like receptor 9 & $\operatorname{tlr} 9$ & B030920 & $\begin{array}{l}\text { F: GATCACACCGTTCACTGTCTC } \\
\text { R: GGAGGAGAGGGACTGGATTC }\end{array}$ & $98.09 \%$ \\
\hline Acetylcholinesterase & ache & B017377 & $\begin{array}{l}\text { F: CGGAGTGGATGGGTGTGATC } \\
\text { R: GTCGGCTCAGTTTCTCCTCC }\end{array}$ & $90.82 \%$ \\
\hline Cathepsin D & ctsd & B000122 & $\begin{array}{l}\text { F: TCGCTGCCTGTTGTCTCTTT } \\
\text { R: GCCCGACAGACAGATTGACA }\end{array}$ & $112.76 \%$ \\
\hline $\begin{array}{l}\text { Cholinergic receptor, nicotinic, } \\
\text { alpha } 7\end{array}$ & chrna7 & B000251 & $\begin{array}{l}\text { F: AATGCCAGCCACAGAGATCC } \\
\text { R: TGATTTGGGTCCAGCTCTGC }\end{array}$ & $109.85 \%$ \\
\hline $\begin{array}{l}\text { NLR family, CARD domain con- } \\
\text { taining } 3\end{array}$ & nlrc3 & B000011 & $\begin{array}{l}\text { F: CTGCCAGTGGTCAAAGCCTC } \\
\text { R: AGGACTGGGAGCTGAGAACT }\end{array}$ & $98.23 \%$ \\
\hline NLR family member X1 & $n l r x 1$ & B002577 & $\begin{array}{l}\text { F: AGGTGTACCAAAGAGCCACG } \\
\text { R: CTGAGGATGGGATGCCAGTC }\end{array}$ & $105.71 \%$ \\
\hline Cathepsin S & ctss & B007924 & $\begin{array}{l}\text { F: AACCTGGTGGACTGTTCGTC } \\
\text { R: GCGTCAGAGTCGATACCCTG }\end{array}$ & $106.63 \%$ \\
\hline Cathepsin L & ctsl & B019572 & $\begin{array}{l}\text { F: ATGATGAGCCAGACTGCAGC } \\
\text { R: AGACCCCAGCTGTTCTTGAC }\end{array}$ & $113.90 \%$ \\
\hline Butyrylcholinesterase & bche & B013682 & $\begin{array}{l}\text { F: CAGGTACTCCCAACACGGTG } \\
\text { R: ATCTCGTAGCCGTGCATGAC }\end{array}$ & $107.75 \%$ \\
\hline Interleukin-10 & il-10 & FG261948 & $\begin{array}{l}\text { F: CTCACATGCAGTCCATCCAG } \\
\text { R: TGTGATGTCAAACGGTTGCT }\end{array}$ & $98.06 \%$ \\
\hline Transforming growth factor 1 beta & $\operatorname{tg} f-1 \beta$ & AF424703 & $\begin{array}{l}\text { F: GCATGTGGCAGAGATGAAGA } \\
\text { R: TTCAGCATGATACGGCAGAG }\end{array}$ & $94.54 \%$ \\
\hline $\begin{array}{l}\text { NLR family, CARD domain con- } \\
\text { taining } 5 \text { (isoform 1) }\end{array}$ & nlrc5 (isof.1) & B003870 & $\begin{array}{l}\text { F: AGCAGCTAGTTTGGCCTCTG } \\
\text { R: GGCGATGTGTTTGATCCCTG }\end{array}$ & $105.93 \%$ \\
\hline
\end{tabular}


Table 1 (continued)

\begin{tabular}{|c|c|c|c|c|}
\hline Gene name & Gene abbreviation & GenBank number & Primer sequences $\left(5^{\prime} \rightarrow 3^{\prime}\right)$ & $\begin{array}{l}\text { Primer efficien- } \\
\text { cies }\end{array}$ \\
\hline $\begin{array}{l}\text { NLR family, CARD domain con- } \\
\text { taining } 5 \text { (isoform 2) }\end{array}$ & nlrc5 (isof.2) & B003870 & $\begin{array}{l}\text { F: CAAGAGTGATGCCCCTGTGT } \\
\text { R: GACTGTGAGGCTCTGAGCAG }\end{array}$ & $81.50 \%$ \\
\hline Ribosomal protein S18 & $\operatorname{rps} 18$ & AM490061 & $\begin{array}{l}\text { F: CGAAAGCATTTGCCAAGAAT } \\
\text { R: AGTTGGCACCGTTTATGGTC }\end{array}$ & $139.43 \%$ \\
\hline Elongation factor-1 alfa & efla & AF184170 & $\begin{array}{l}\text { F: TGTCATCAAGGCTGTTGAGC } \\
\text { R: GCACACTTCTTGTTGCTGGA }\end{array}$ & $110.84 \%$ \\
\hline Actin beta & $a c t b$ & X89920 & $\begin{array}{l}\text { F: GGCACCACACCTTCTACA } \\
\text { AATG } \\
\text { R: GTGGTGGTGAAGCTGTAGCC }\end{array}$ & $103.07 \%$ \\
\hline
\end{tabular}

was previously assessed using a Shapiro-Wilk test and homogeneity of variance was also verified using the Levene test. Non-normally distributed data were log-transformed to perform parametric tests while non-parametric Kruskal-Wallis test, followed by a Dunn's multiple comparison test, was used when data did not meet parametric assumptions. All statistical analyses were conducted using the computer package SPSS (25.0 version; SPSS Inc., Chicago, IL, USA) for WINDOWS. The level of significance used was $P<0.05$ for all statistical tests.

\section{Results}

Protein prediction analysis

To assess the conservation and functional interactions of the proteins involved in the inflammatory process, 40 gilthead seabream proteins were compared with protein sequences of other teleosts that appeared to match the input proteins in the STRING database (Table 2). The large yellow croaker was selected for the analysis due to the higher number of proteins that matched the gilthead seabream protein sequence and the higher homology of its proteins (identity) with those of the gilthead seabream compared to the other teleosts. Gilthead seabream proteins were divided into three groups (cell markers and pro-inflammatory and anti-inflammatory proteins) according to their percentages of identity (Table 3 ).

Cell marker proteins of the gilthead seabream sequence showed percentages of identity with that of yellow croaker ranging between 67.1 and $91.4 \%$.
PHOX40 was the protein with the highest percentage (91.4\%), followed by CSF1R (91\%) and PHOX22 $(89.7 \%)$. MHC-II showed the lowest percentage of identity (67.1\%) (Table 3).

Pro-inflammatory proteins derived from the gilthead seabream protein sequence presented percentages of identity with that of yellow croaker ranging between 44.6 and $97.8 \%$ (Table 3). The protein

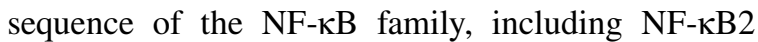
(97.8\%), RelA (82.3\%), NF-кB1 (82\%), C-Rel $(81.3 \%)$, and RelB (81.1\%), was the subgroup with the highest percentage of identity, while the TNR superfamily, including TNFRSFa (72.9\%) and TNFRSF1b (44.6\%), presented the lowest percentage of identity. The adaptor protein sequences (STAT3, 96.7\%; TRAF6, 89.1\%; IкBKG, 83.2; MYD88, 83\%; IRAK1, 66.1\%), the protein sequence of the TLR family (TLR2, 85\%; TLR5, 70\%; TLR7, 69.4\%; TLR8, 64.6\%; TLR13, 49.7\%), and the sequence of cytokines (TNF- $\alpha, 84.7 \%$; IL-1 $\beta, 62.1 \%$ ) showed an intermediate identity percentage range. No associations were found between the IL-6, IL-7, IL-8, IL-18, and TLR9 proteins of the two species.

The identity of anti-inflammatory proteins was more homogeneous than that of pro-inflammatory proteins, with a range of identity between 59.9 and 91.3\% (Table 3). The cholinergic protein sequences (AChE, 91.3\%; nAChR $\alpha 7,89.1 \%$; BChE, 76.8\%) showed the highest percentages of identity, the cathepsin sequence (CTSD, 90.4\%; CTSS; 85.7\%; CTSL, 85.4\%) presented intermediate ranges, and the anti-inflammatory cytokines (IL-10, 76.4\%; TGF- $\beta 1,72.5 \%$ ) presented lower percentages of identity. On the other hand, the NOD-like receptor 
family sequences showed a wider range, with NLRC3 $(88.2 \%)$ and NLRX1 (86.9\%) exhibiting higher identity percentages than NLRC5 isoforms $1(70.3 \%)$ and $2(59.9 \%)$.

Functional protein association network analysis

The functional association network analysis revealed that 34 nodes (functional proteins) selected from the gilthead seabream sequence interacted in large yellow croaker (Larimichthys crocea) (Table 4). These 34 nodes represented 125 edges (specific and meaningful associations). The average node degree provided by STRING, which represents the number of interactions (at the score threshold) that a protein has on the average in the network, had a value of 7.35 , while the clustering coefficient (a measure of how closely connected the nodes in the network are) had a value of 0.688 (Fig. 1).

Gene expression analysis

Real-time PCR was used to analyze the expression profile of 4 cell markers, 24 pro-inflammatory genes, and 12 anti-inflammatory genes in fish skin samples collected 12 and $24 \mathrm{~h}$ after carrageenin or PBS injection.

Cell markers The expression of the csflr gene (macrophage marker) $12 \mathrm{~h}$ after carrageenin injection was significantly downregulated in comparison to that of control specimens (Fig. 2A). On the other hand, although no significant differences $(p>0.05)$ were observed either at 12 or at $24 \mathrm{~h}$ in the expression of phox 22 and phox 40 (acidophilic granulocyte markers) or mhciia (antigen-presenting cell marker) genes (Fig. 2B-2D), an ascendant tendency in the expression of phox 22 and phox 40 was found in the carrageenin group $24 \mathrm{~h}$ after injection with respect to the control group.

Pro-inflammatory genes The administration of carrageenin produced no statistically significant differences in the expression of c-rel between the carrageenin and control groups $12 \mathrm{~h}$ after injection. However, this gene was significantly upregulated at $24 \mathrm{~h}$ in the carrageenin group in comparison with the control group (Fig. 3A). Interestingly, no significant differences were found between the two groups in the gene expression of many other pro-inflammatory genes

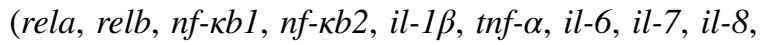
il-18, tlr2, tlr5, tlr7, tlr8, tlr9, tlr13, tnfrsfla, tnfrsflb, myd88, irakl, traf6, stat3, ikbkg) either at 12 or at $24 \mathrm{~h}$ after injection (Figs. 3, 4, 5 and 6).

Anti-inflammatory genes The injection of carrageenin resulted in no significant changes in the expression of anti-inflammatory genes (il-10, tgf- $\beta 1$, ctsd, ctsl, ctss, nlrc3, nlrc5 isoforms 1 and 2, nlrxl, ache, bche, and chrna7) with respect to the control group either at 12 or at $24 \mathrm{~h}$ (Figs. 7 and 8). All the results of the gene expression analysis are summarized in a schematic inflammatory model shown in Fig. 9.

\section{Discussion}

Although inflammation has been extensively studied in mammals, it is possible that not all the transduction pathways of this process have been conserved in the

Table 2 Similar organisms that match the gilthead seabream (Sparus aurata) protein sequence ordered according to the number of proteins matched

\begin{tabular}{lll}
\hline Organism & $\begin{array}{l}\text { Number } \\
\text { of proteins } \\
\text { matched }\end{array}$ & $\begin{array}{l}\text { Range of proteins } \\
\text { identity matched }\end{array}$ \\
\hline Stegastes partitus & 36 & $93.8-40.2 \%$ \\
Larimichthys crocea & 35 & $97.8-44.6 \%$ \\
Maylandia zebra & 35 & $96.0-49.3 \%$ \\
Neolamprologus brichardi & 35 & $91.7-41.8 \%$ \\
Oreochromis niloticus & 35 & $95.9-37.6 \%$ \\
Oryzias latipes & 35 & $90.4-32.4 \%$ \\
Poecilia reticulata & 35 & $91.2-35.6 \%$ \\
Xiphophorus maculatus & 35 & $94.3-35.9 \%$ \\
Cynoglossus semilaevis & 34 & $95.5-32.2 \%$ \\
Haplochromis burtoni & 34 & $98.7-45.0 \%$ \\
Poecilia formosa & 34 & $94.2-39.5 \%$ \\
Pundamilia nyererei & 34 & $95.9-46.4 \%$ \\
Esox lucius & 33 & $86.6-40.3 \%$ \\
Gasterosteus aculeatus & 33 & $94.6-36.8 \%$ \\
Astyanax mexicanus & 32 & $93.5-36.1 \%$ \\
Danio rerio & 31 & $93.1-36.3 \%$ \\
Takifugu rubripes & 31 & $94.6-34.6 \%$ \\
Lepisosteus oculatus & 30 & $91.5-32.8 \%$ \\
Gadus morhua & 28 & $95.2-38.5 \%$ \\
\hline & & \\
\hline & 35 & \\
\hline & 35 & \\
\hline
\end{tabular}


Table 3 Protein prediction analysis between gilthead seabream (Sparus aurata) and Larimichthys crocea ordered from the highest to the lowest identity

\begin{tabular}{|c|c|c|c|c|c|}
\hline & S. aurata proteins & $\begin{array}{l}\text { Matching proteins in } \\
\text { L. crocea }\end{array}$ & Annotation & Identity & $e$-value \\
\hline \multirow[t]{4}{*}{ Cell marker } & PHOX40 & NCF4 & Neutrophil cytosol factor 4 & $91.5 \%$ & $8.4 \mathrm{e}-133$ \\
\hline & CSF1R & CSF1R1 & Macrophage colony-stimulating factor 1 receptor isoform $\mathrm{X} 1$ & $91.0 \%$ & 0.0 \\
\hline & PHOX22 & XP_010739797.1 & Cytochrome b-245 light chain & $89.7 \%$ & $8 \mathrm{e}-85$ \\
\hline & MHC-II & XP_010754186.1 & $\begin{array}{l}\text { The sequence of the model RefSeq protein was modified relative to its } \\
\text { source genomic sequence to represent the inferred CDS: added } 285 \\
\text { bases not found in genome assembly }\end{array}$ & $67.1 \%$ & $6.8 \mathrm{e}-84$ \\
\hline \multirow{21}{*}{$\begin{array}{l}\text { Pro-inflamma- } \\
\text { tory proteins }\end{array}$} & $\mathrm{NF}-\kappa \mathrm{B} 2$ & NFKB2 & Nuclear factor NF-kappa-B p100 subunit isoform X1 & $97.8 \%$ & $2.4 \mathrm{e}-205$ \\
\hline & STAT3 & STAT3 & Signal transducer and activator of transcription 3 isoform $\mathrm{X} 1$ & $96.7 \%$ & 0.0 \\
\hline & TRAF6 & TRAF6 & $\begin{array}{l}\text { TNF receptor-associated factor } 6 \text {; the sequence of the model RefSeq } \\
\text { protein was modified relative to its source genomic sequence to } \\
\text { represent the inferred CDS: deleted } 1 \text { base in } 1 \text { codon }\end{array}$ & $89.1 \%$ & $6.5 \mathrm{e}-311$ \\
\hline & TLR2 & EH28_06854 & Toll-like receptor 2 type- 2 & $85.0 \%$ & $1.7 \mathrm{e}-108$ \\
\hline & $\mathrm{TNF}-\alpha$ & EH28_05037 & Tumor necrosis factor-like & $84.7 \%$ & $3.5 e-28$ \\
\hline & IкBKG & IKBKG & $\begin{array}{l}\text { Inhibitor of nuclear factor kappa B kinase subunit gamma; NF-kappa-B } \\
\text { essential modulator isoform X1 }\end{array}$ & $83.2 \%$ & $2.2 \mathrm{e}-245$ \\
\hline & MYD88 & MYD88 & Myeloid differentiation primary response protein MyD88 & $83.0 \%$ & $1.4 \mathrm{e}-139$ \\
\hline & RelA & RELA & $\begin{array}{l}\text { Transcription factor p65; the sequence of the model RefSeq protein } \\
\text { was modified relative to its source genomic sequence to represent the } \\
\text { inferred CDS: deleted } 1 \text { base in } 1 \text { codon }\end{array}$ & $82.3 \%$ & $3.7 e-283$ \\
\hline & NF- $\kappa$ B 1 & NFKB1 & $\begin{array}{l}\text { The sequence of the model RefSeq protein was modified relative to its } \\
\text { source genomic sequence to represent the inferred CDS: deleted } 4 \\
\text { bases in } 3 \text { codons }\end{array}$ & $82.0 \%$ & $3.8 \mathrm{e}-36$ \\
\hline & C-Rel & EH28_06409 & Proto-oncogene c-Rel & $81.3 \%$ & $3 e-304$ \\
\hline & RelB & RELB & Transcription factor RelB & $81.1 \%$ & $1.5 e-265$ \\
\hline & TNFRSF1A & EH28_04263 & $\begin{array}{l}\text { Tumor necrosis factor receptor superfamily member } 1 \mathrm{~A} \text {; derived by } \\
\text { automated computational analysis using gene prediction method: } \\
\text { Gnomon. Supporting evidence includes similarity to: } 1 \text { Protein, and } \\
100 \% \text { coverage of the annotated genomic feature by RNAseq align- } \\
\text { ments, including } 2 \text { samples with support for all annotated introns }\end{array}$ & $72.9 \%$ & $2.5 e-85$ \\
\hline & TLR5 & XP_010754180.1 & Toll-like receptor 5 & $70.2 \%$ & $4.6 e-63$ \\
\hline & TLR7 & TLR7 & Toll-like receptor 7 & $69.4 \%$ & $3.8 \mathrm{e}-24$ \\
\hline & IRAK1 & EH28_12873 & Interleukin-1 receptor-associated kinase 1-like & $66.1 \%$ & $2.8 \mathrm{e}-176$ \\
\hline & TLR8 & XP_010741343.1 & Toll-like receptor 8 & $64.6 \%$ & $5.5 e-198$ \\
\hline & IL-1 $\beta$ & IL-1 $\beta$ & Interleukin-1 beta-like & $62.1 \%$ & $9 \mathrm{e}-79$ \\
\hline & TLR13 & EH28_03283 & $\begin{array}{l}\text { Toll-like receptor 13; derived by automated computational analysis } \\
\text { using gene prediction method: Gnomon. Supporting evidence } \\
\text { includes similarity to: } 48 \text { proteins }\end{array}$ & $49.7 \%$ & $3.2 \mathrm{e}-82$ \\
\hline & TNFRSF1B & TNFRSF1B & $\begin{array}{l}\text { Tumor necrosis factor receptor superfamily member 1B; derived by } \\
\text { automated computational analysis using gene prediction method: } \\
\text { Gnomon. Supporting evidence includes similarity to: } 4 \text { proteins, and } \\
100 \% \text { coverage of the annotated genomic feature by RNAseq align- } \\
\text { ments, including } 3 \text { samples with support for all annotated introns }\end{array}$ & $44.6 \%$ & $1.2 \mathrm{e}-95$ \\
\hline & IL-7 & $\begin{array}{l}\text { [STRING found no } \\
\text { matching protein in } \\
\text { its database] }\end{array}$ & - & - & - \\
\hline & IL-18 & $\begin{array}{l}\text { [STRING found no } \\
\text { matching protein in } \\
\text { its database] }\end{array}$ & - & - & - \\
\hline
\end{tabular}


Table 3 (continued)

\begin{tabular}{|c|c|c|c|c|c|}
\hline & S. aurata proteins & $\begin{array}{l}\text { Matching proteins in } \\
\text { L. crocea }\end{array}$ & Annotation & Identity & $e$-value \\
\hline & IL-6 & - & - & - & - \\
\hline & IL-8 & - & - & - & - \\
\hline & TLR9 & - & - & - & - \\
\hline \multirow{12}{*}{$\begin{array}{l}\text { Anti-inflamma- } \\
\text { tory proteins }\end{array}$} & $\mathrm{AChE}$ & ACHE & Acetylcholinesterase & $91.3 \%$ & 0.0 \\
\hline & CTSD & XP_010735640.1 & Cathepsin D-like & $90.4 \%$ & $2 \mathrm{e}-213$ \\
\hline & $\mathrm{nAChR} \alpha 7$ & EH28_10415 & $\begin{array}{l}\text { Neuronal acetylcholine receptor subunit alpha-7; derived by automated } \\
\text { computational analysis using gene prediction method: Gnomon. Sup- } \\
\text { porting evidence includes similarity to: } 11 \text { proteins }\end{array}$ & $89.1 \%$ & $6.5 e-24$ \\
\hline & NLRC3 & EH28_01217 & Protein NLRC3-like & $88.2 \%$ & $4 e-57$ \\
\hline & NLRX1 & NLRX1 & NLR family member X1 & $86.9 \%$ & 0.0 \\
\hline & CTSS & CTSS & Cathepsin S & $85.7 \%$ & $3.5 e-34$ \\
\hline & CTSL & EH28_09355 & Cathepsin L1-like & $85.4 \%$ & $1.8 \mathrm{e}-172$ \\
\hline & $\mathrm{BChE}$ & XP_010750341.1 & Acetylcholinesterase-like & $76.8 \%$ & $1.2 \mathrm{e}-267$ \\
\hline & IL-10 & IL10 & Interleukin-10 & $76.4 \%$ & $3.1 \mathrm{e}-34$ \\
\hline & TGF- $\beta$ & XP_010748216.1 & Transforming growth factor beta-1-like & $72.5 \%$ & $8.8 \mathrm{e}-155$ \\
\hline & NLRC5 Iso 1 & NLRC5 & NLR family CARD domain containing 5 & $70.3 \%$ & 0.0 \\
\hline & NLRC5 Iso 2 & NLRC5 & NLR family CARD domain containing 5; protein NLRC5-like & $59.9 \%$ & $4 \mathrm{e}-170$ \\
\hline
\end{tabular}

evolution of vertebrates (Byadgi et al. 2018; Savan and Sakai 2006). To our knowledge, this is the first study to investigate the conservation of inflammatory pathways in fish using the STRING database to identify functional associations of inflammationrelated proteins applicable to the gilthead seabream (Balasch and Tort 2019; Cordero et al. 2017; Sarropoulou et al. 2007; Silva-Marrero et al. 2017; Tsakogiannis et al. 2019). In our analysis, L. crocea, a species of particular interest for the marine aquaculture of the north-western Pacific, was the species whose protein sequence seemed to most closely match that of the gilthead seabream (Tan et al. 2019; Wang et al. 2016). It can be assumed that the analyzed proteins are highly conserved between the gilthead seabream and yellow croaker, since protein sequences with $>25 \%$ identity are considered orthologs (genes homologous by speciation) at the protein level and could be used to predict their molecular functions (Konaté et al. 2017). Furthermore, none of the studied sequences showed a percentage of identity less than $30 \%$, the threshold below which protein structures degenerate (Gilson et al. 2017). Moreover, the 34 nodes obtained represented 125 edges, while the number of expected edges for a random set of proteins of the yellow croaker genome was 4 . This high number suggests that the selected proteins are, at least partially, biologically connected (not necessarily physically bound but with some specific and meaningful associations), suggesting a shared function. These proteins are quite likely associated with inflammation (Postlethwait et al. 2000). It is noteworthy that the level of molecular conservation of cell markers CSF1R (also known as macrophage colony-stimulating factor receptor, MCSFR) and PHOX40, and PHOX22 between the gilthead seabream and large yellow croaker was significantly high (identity percentage close to $90 \%$ ). These are important biomarkers for macrophages and acidophilic granulocytes (Grayfer et al. 2009; Meseguer et al. 1994). Interestingly, although the catalytic tyrosine kinase domains of CSF1R are highly conserved among vertebrates, it seems that csflr genes exhibit a low sequence identity (especially in their extracellular domains), which could be reflected in the low conservation of the CSF1R ligand and the distinct macrophage functionality across divergent species (Grayfer et al. 2018). Likewise, the catalytic domains of PHOX22 and PHOX40, which are transmembrane and cytosol proteins, respectively, of the NADPH oxidase enzyme system of gilthead 
Table 4 Functional protein association networks of Larimichthys crocea obtained from the gilthead seabream (Sparus aurata) protein sequence

\begin{tabular}{llllll}
\hline $\begin{array}{l}\text { Number } \\
\text { of nodes }\end{array}$ & $\begin{array}{l}\text { Number } \\
\text { of edges }\end{array}$ & $\begin{array}{l}\text { Average } \\
\text { node } \\
\text { degree }\end{array}$ & $\begin{array}{l}\text { Avg. } \\
\text { local } \\
\text { cluster- } \\
\text { ing } \\
\text { coef- } \\
\text { ficient }\end{array}$ & $\begin{array}{l}\text { Expected } \\
\text { number } \\
\text { of edges }\end{array}$ & $\begin{array}{l}\text { PPI } \\
\text { enrich- } \\
\text { ment } \\
p \text {-value }\end{array}$ \\
\hline 34 & 125 & 7.35 & 0.688 & 6 & $<1.0 \mathrm{e}-16$ \\
\hline
\end{tabular}

seabream acidophilic granulocytes, are highly conserved (Belambri et al. 2018; Kawahara and Lambeth 2007; Meseguer et al. 1994; Sepulcre et al. 2002). In contrast, the basic pattern of MHC variation in mammals (Dijkstra et al. 2013; Yamaguchi and Dijkstra 2019) that has remained in fish with a high level of allelic/haplotype diversification explains the lower percentage of identity of MHC-II compared to the other cell markers in our study.

Regarding pro-inflammatory proteins, we found a high conservation level of proteins related to the NF- $\kappa \mathrm{B}$ family, consisting of five polypeptide subunits-RelA (p65), RelB, C-Rel, NF-кB1 (p50/ $\mathrm{p} 105)$, and NF- $\mathrm{BB} 2$ (p52/p100). This could be due to the key role that this transcription factor plays in the activation and release of pro-inflammatory cytokines, as well as its implication in the expression of pro-survival molecules involved in the regulation of important processes, such as the immune response and homeostasis maintenance (Etemadi et al. 2015; Gugasyan et al. 2004; Mulero et al. 2019; Napetschnig and Wu 2013). This is also supported by the relatively highly conserved adaptors and regulatory proteins (STAT3, TRAF6, IкBKG, MYD88, and IRAK1), which might be critical for maintaining a minimal threshold of NF- $\mathrm{KB}$ signalling and whose activity could also be regulated by intracellular homeostatic processes, such as oxidative stress, metabolite changes, and DNA damage (Hinz et al. 2010; Linares et al. 2013; Matsuzawa et al. 2005; Moscat and DiazMeco 2016; Rezaeian et al. 2017; Tang et al. 2013; Tzeng et al. 2013; Zhang et al. 2016).

Likewise, the high percentage of identity (around $85 \%$ ) of anti-inflammatory proteins, such as cholinergic proteins and cathepsins, could also be related to their regulatory function. For instance, facing an inflammatory response, the nervous system of higher organisms can release acetylcholine through the efferent vagus nerve, which is activated by $\mathrm{AChE}$ and $\mathrm{BChE}$, and inhibit the production of pro-inflammatory cytokines in macrophages via activation of the $\alpha 7$-nicotinic homopentameric receptor $(\alpha 7 \mathrm{nAChR})$ (Zila et al. 2017). It has been observed in human cell lines that NOD-like receptors, such as NLRC3, may also downregulate the expression of NF- $\mathrm{KB}$ transcription factor by TRAF6 ubiquitination, while mitochondrial NLRX1 and NLRC5 limit the NF- $\mathrm{KB}$ activation by interfering with the interactions of the TRAF6IKK (IK-B kinase) protein complex and the IKK $\alpha$ protein, respectively (Cui et al. 2010; Schneider et al. 2012; Xia et al. 2011). Cathepsins, for their part, not only are lysosomal endonucleases that negatively modulate inflammation but are also involved in cell survival and apoptosis, participating, among other functions, in neutrophil recruitment (CTSL), caspase activation (CTSD), and process and maturation of the associated invariant chain of MHC-II (CTSS) (Conus et al. 2008; Conus and Simon 2008; Li et al. 2015).

It is important to emphasize the ancient genome duplication that occurred in teleosts, whereby an estimated $30 \%$ of genes were duplicated. This could explain the main protein sequence differences found in our assay (Postlethwait et al. 2000). It could also support the high conservation of molecules involved in the regulatory pathways of the immune response (such as the NF- $\mathrm{KB}$ family transcription factors). On the other hand, secondary mediators (such as proinflammatory and anti-inflammatory cytokines and proteins of the TLR and NOD families and the TNR superfamily) could vary structurally or sequentially depending on the organism, preserving their functions to a greater or lesser extent in most teleost fishes as paralogues (multiple copies) (Mulero et al. 2019; Secombes et al. 2011; Wang and Secombes 2013). This also explains the presence of two isoforms of NLRC5 in the gilthead seabream, whose protein sequence seems to coincide to some degree with the NLRC5 protein sequence of $L$. crocea, suggesting that NLRC5 isoform 1 of the gilthead seabream could be more conserved than isoform 2 .

To validate the in silico results obtained from the STRING database and to confirm the conservation of the molecules involved in the inflammatory response of the gilthead seabream, an in vivo analysis of the gene expression was performed using carrageenin as a stimulus of inflammation according to the schema 


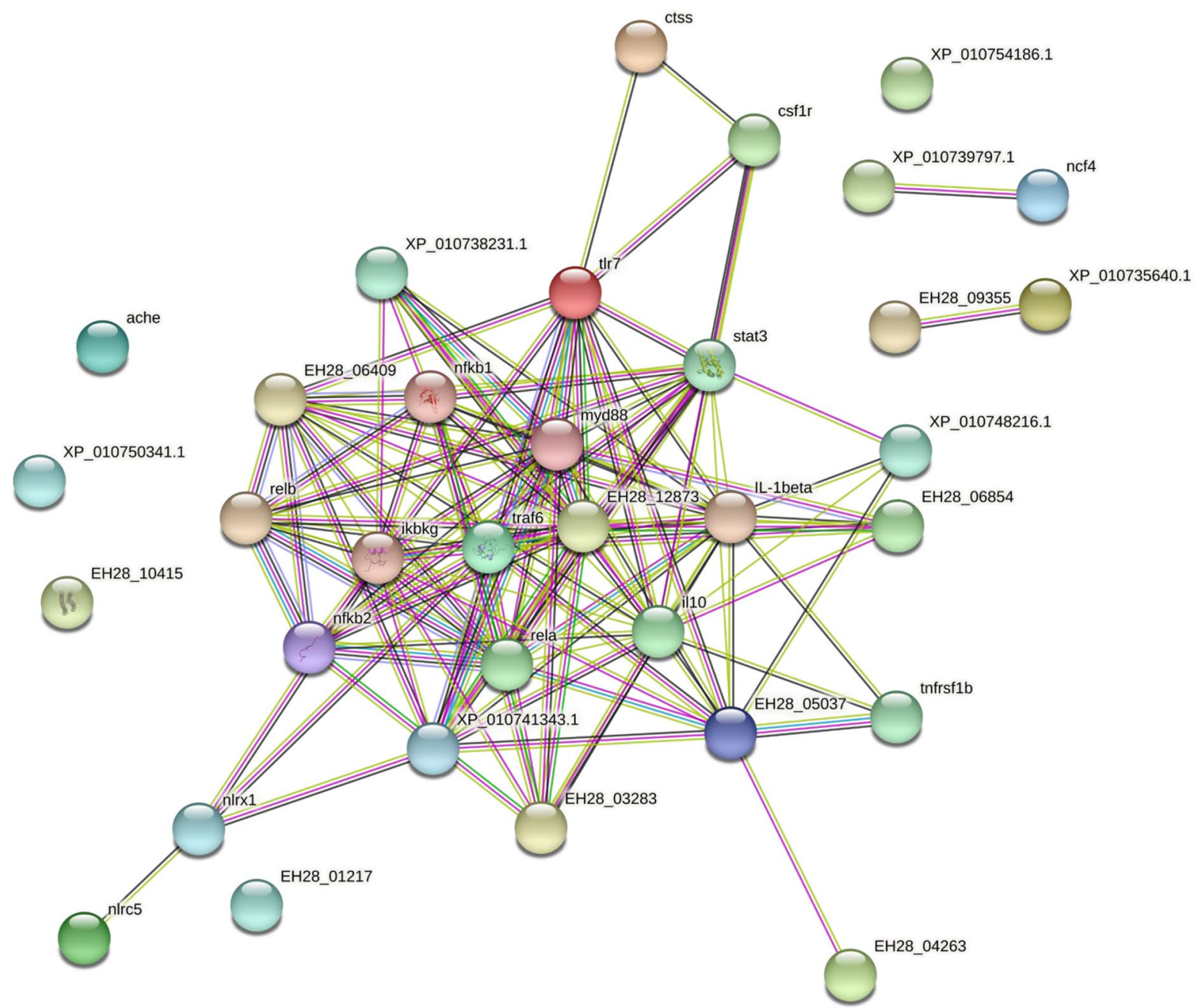

Fig.1 Representation of the node network (selected proteins) of Larimichthys crocea generated from the Sparus aurata protein sequence using the STRING database (see protein annotation in Table 3). The different edge colors indicate the type of evidence for each interaction: cyan = curated STRING data-

shown in Fig. 9. The concentration of injected carrageenin $(50 \mu \mathrm{l}$ of $1 \%$ carrageenin) and the sampling times (12 and $24 \mathrm{~h}$ after injection) were carefully chosen considering the available data from studies on mammals (Levy 1969; Morris 2003; Winter et al. 1962). Nonetheless, although proteins seem to be relatively highly conserved, some key considerations are important for understanding the functional differences between studied organisms and the effects of carrageenin on the gilthead seabream. For instance, unlike in mammals, leucocytes in fish should migrate from the head kidney (the main hematopoietic organ) base; purple $=$ experimentally determined; green = gene neighborhood; blue = gene co-occurrence; light green = text mining; black $=$ co-expression; lavender $=$ protein homology (the types of evidence are not mutually exclusive)

to the injured site when an insult is perceived by local cells (Meseguer et al. 1995), such as the presence of carrageenin in this study. Therefore, infiltrating acidophilic granulocytes of the gilthead seabream, which are functionally equivalent to mammalian neutrophils (Meseguer et al. 1994; Sepulcre et al. 2002), should be the first cells to be recruited to the inflammation site, followed by macrophages (Kolaczkowska and Kubes 2013; Medzhitov 2008; Nathan 2006; NguyenChi et al. 2015).

The observed downregulation of csflr expression $12 \mathrm{~h}$ after carrageenin injection suggests a 
Fig. 2 Relative expression of A csfrl, B phox $22, \mathbf{C}$ phox40, and $\mathbf{D}$ mhciia in gilthead seabream injected with PBS (control, white bars) and carrageenin ( $1 \%$, black bars) analyzed in skin samples collected 12 and $24 \mathrm{~h}$ after injection. The bars represent the mean \pm standard error of the mean $(n=4)$. The asterisks denote significant differences between the carrageenin and control groups (two-way ANOVA; $p<0.05)$
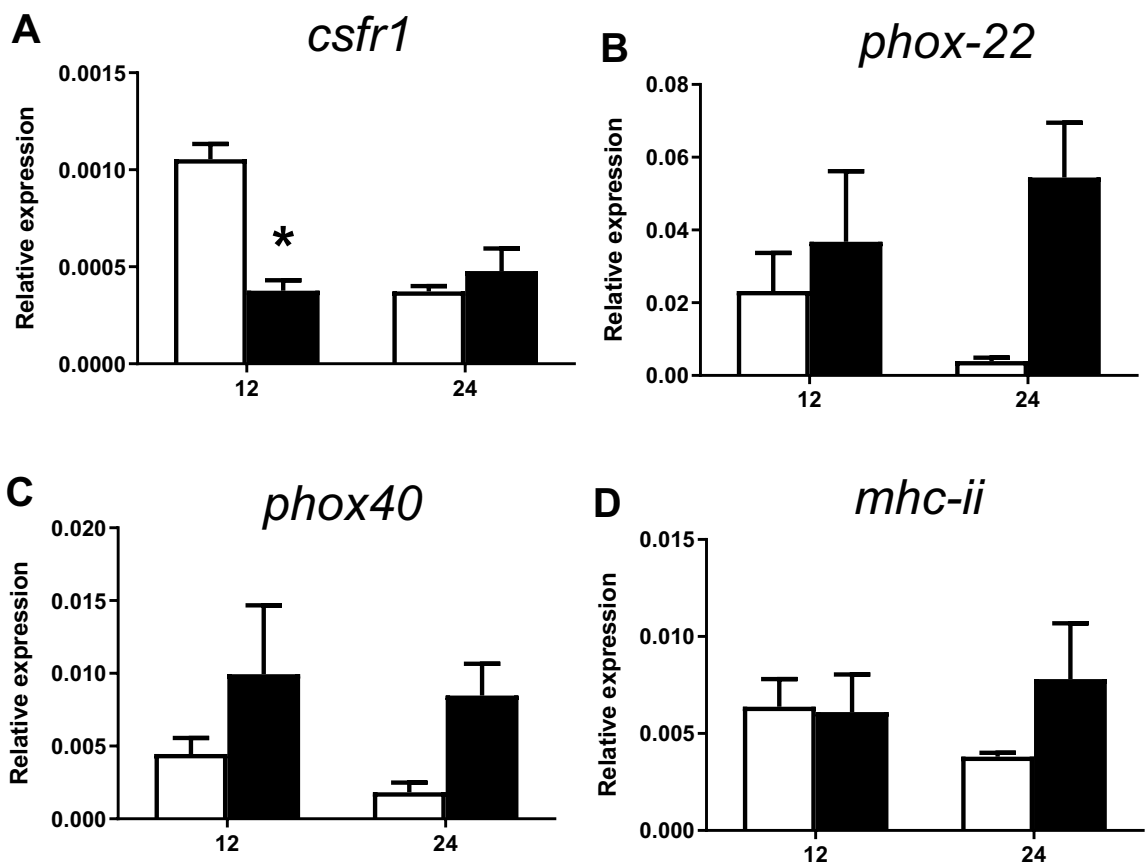

\section{Experimental time (h)}
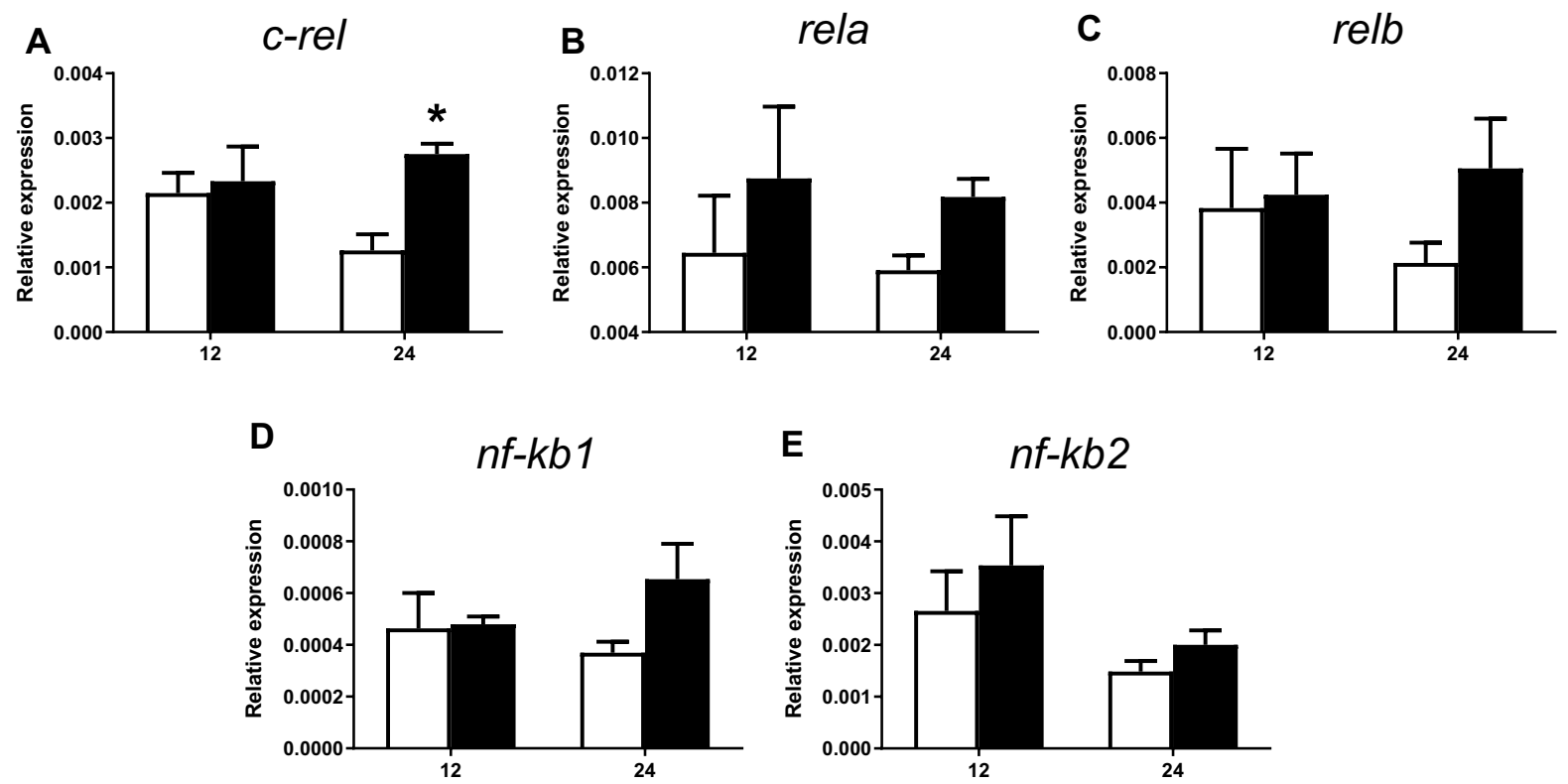

Experimental time (h)

Fig. 3 Relative expression of A c-rel, $\mathbf{B}$ rela, $\mathbf{C}$ relb, $\mathbf{D} n f-\kappa b 1$, and $\mathbf{E} n f-\kappa b 2$ in gilthead seabream injected with PBS (control, white bars) and carrageenin (1\%, black bars) analyzed in skin samples collected 12 and $24 \mathrm{~h}$ after injection. The bars repre- sent the mean \pm standard error of the mean $(n=4)$. The asterisks denote significant differences between the carrageenin and control groups (two-way ANOVA; $p<0.05$ ) 
A

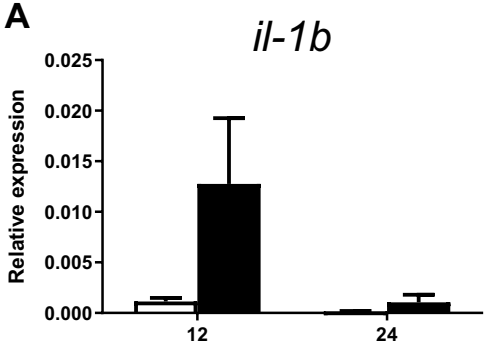

D

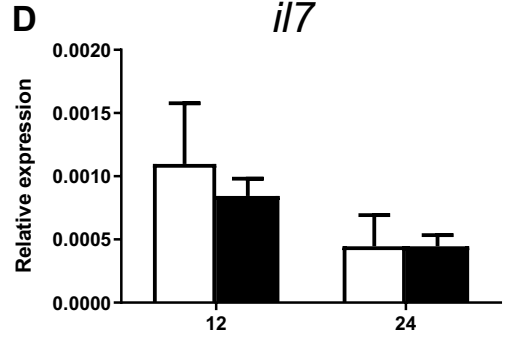

B

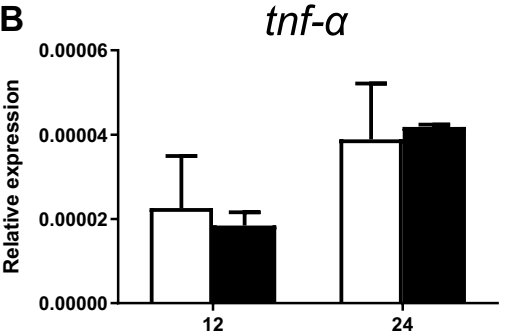

E

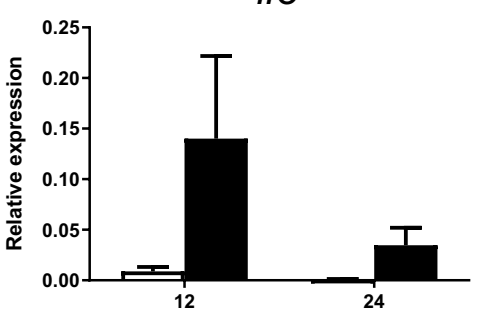

C il6

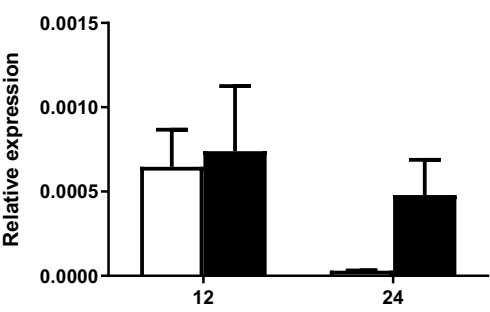

$\mathbf{F}$

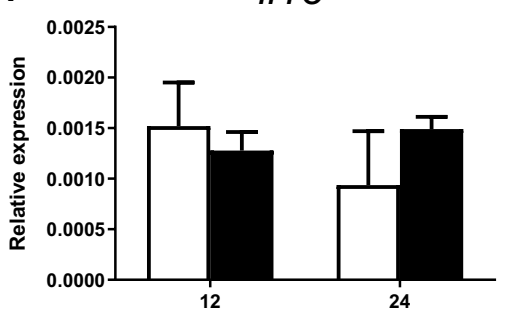

Experimental time $(h)$

Fig. 4 Relative expression of A il-1 $\beta, \mathbf{B}$ tnf- $\alpha$, C il-6, D il$7, \mathbf{E} i l-8$, and $\mathbf{F} i l-18$ in gilthead seabream injected with PBS (control, white bars) and carrageenin (1\%, black bars) analyzed in skin samples collected 12 and $24 \mathrm{~h}$ after injection. The bars represent the mean \pm standard error of the mean $(n=4)$. No significant differences were obtained neither between the carrageenin and control groups nor between the sampling time points (two-way ANOVA $p<0.05$ )
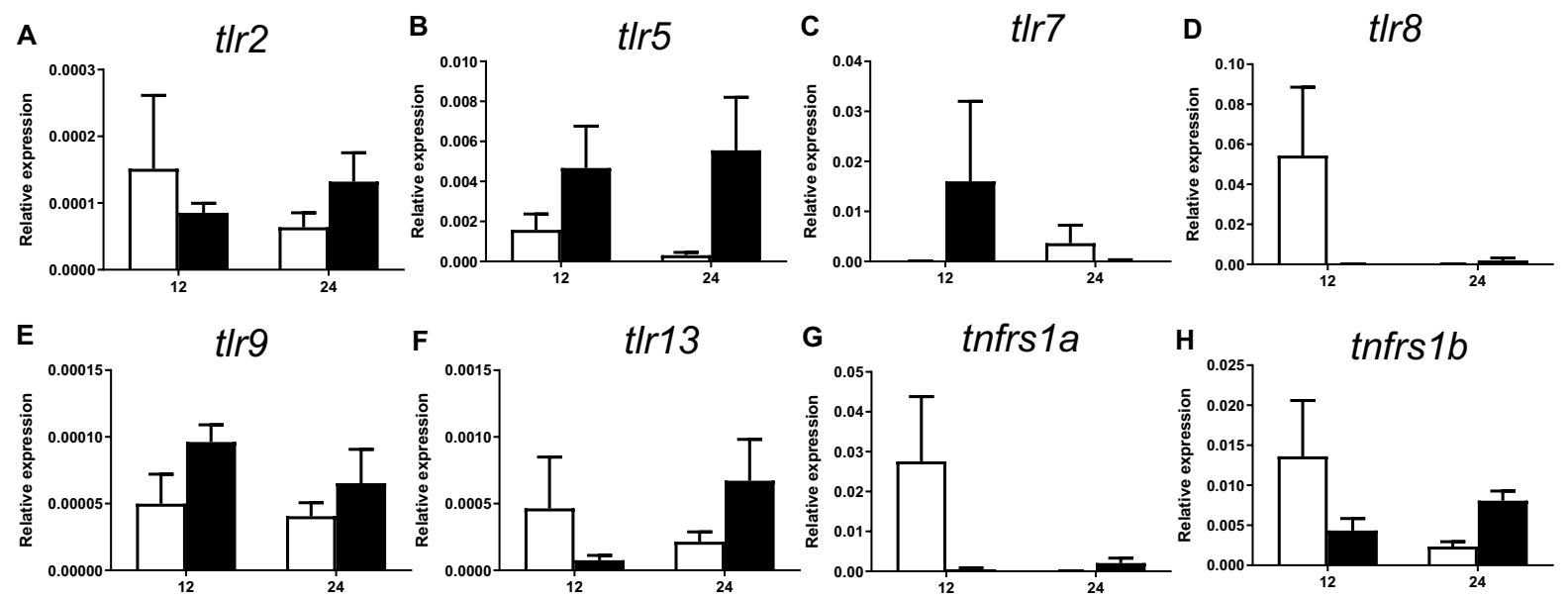

\section{Experimental time $(\mathrm{h})$}

Fig. 5 Relative expression of A $t \operatorname{lr} 2, \mathbf{B} t \operatorname{tr} 5, \mathbf{C} t \operatorname{tr} 7, \mathbf{D} t \operatorname{tr} 8, \mathbf{E}$ $t l r 9, \mathbf{F} t l r 13$, $\mathbf{G}$ tnfrsfla, and $\mathbf{H}$ tnfrsflb in gilthead seabream injected with PBS (control, white bars) and carrageenin (1\%, black bars) analyzed in skin samples collected 12 and $24 \mathrm{~h}$

cytotoxic effect on macrophages since csflr is an important biomarker for teleost fish macrophage after injection. The bars represent the mean \pm standard error of the mean $(n=4)$. No significant differences were obtained neither between the carrageenin and control groups nor between the sampling time points (two-way ANOVA; $p<0.05$ )

survival, proliferation, and differentiation (Hanington et al. 2009; Roca et al. 2006). Studies on mice 

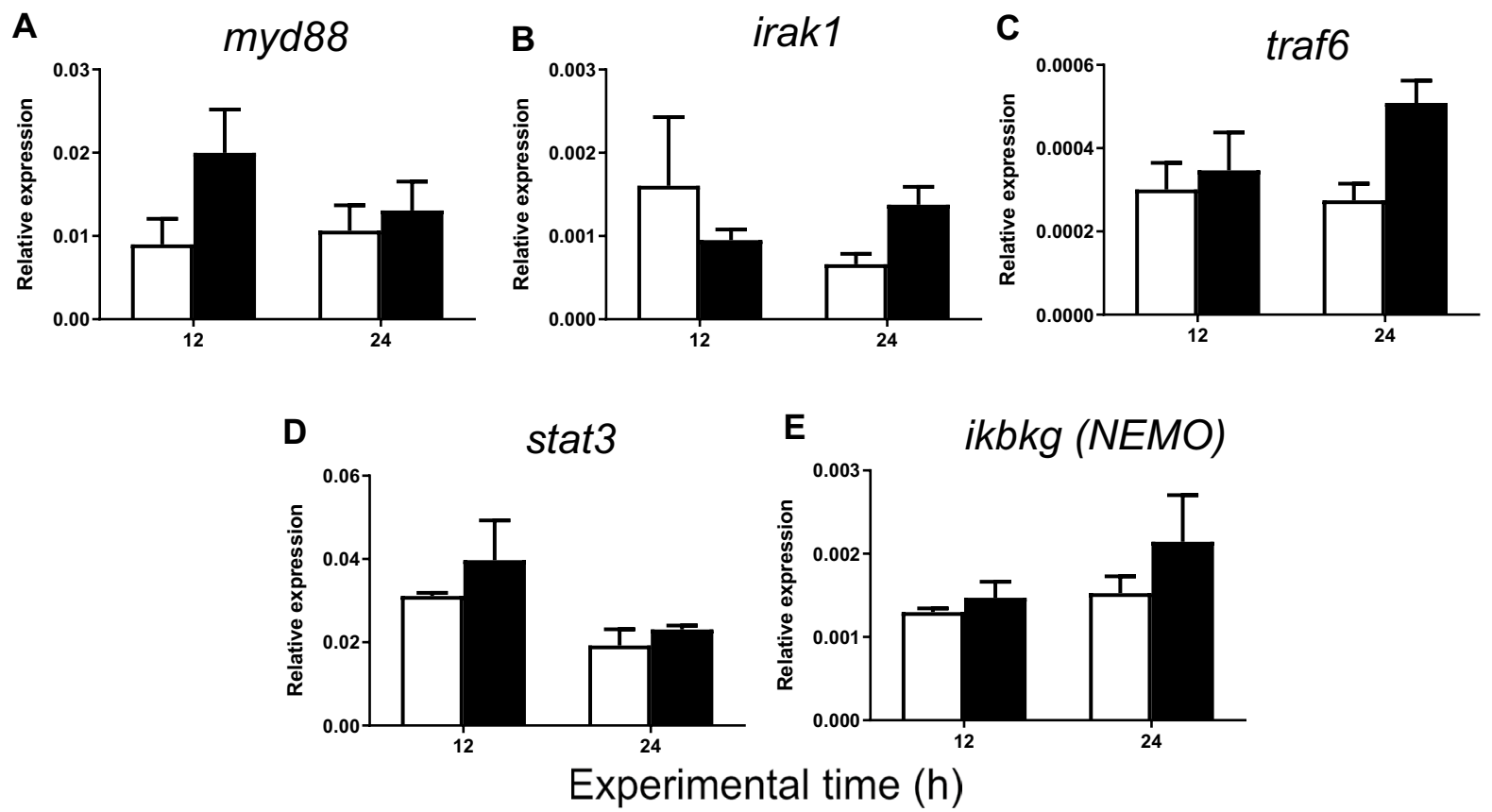

Fig. 6 Relative expression of A myd88, B irak1, C traf6, D stat3, and $\mathbf{E}$ ikbkg (NEMO) in gilthead seabream injected with PBS (control, white bars) and carrageenin (1\%, black bars) analyzed in skin samples collected 12 and $24 \mathrm{~h}$ after

(Mus musculus), guinea pigs (Cavia porcellus), and zebrafish (Danio rerio) have shown that carrageenin can specifically deplete macrophages without affecting neutrophil activity (Kaneda et al. 1991; Mitsuyama et al. 1982; Phelps and Neely 2007), which lends weight to the hypothesis of a cytotoxic effect of carrageenin on gilthead seabream macrophages. Furthermore, the observed increase tendency of phox 22 and phox 40 at both 12 and $24 \mathrm{~h}$ after carrageenin injection suggests the activation or increased recruitment of acidophilic granulocytes to the inflammation site at that time. However, further studies are needed to elucidate the effect of carrageenin at the subcellular level and confirm these hypotheses (Belambri et al. 2018).

Otherwise, and regarding the subunits of $\mathrm{NF}-\kappa \mathrm{B}$ transcription factor in mammals, it would be important to consider that RelA:NF- $\kappa \mathrm{B} 1$ heterodimer is the principal product that induces the canonical signalling pathway of inflammation. RelB:NF- $\mathrm{KB} 2$ constitutes the non-canonical or alternative activation pathway, leaving c-REL subunit as a secondary molecule in this process (Mulero et al. 2019). Interestingly, the injection. The bars represent the mean \pm standard error of the mean $(n=4)$. No significant differences were obtained neither between the carrageenin and control groups nor between the sampling time points (two-way ANOVA; $p<0.05$ )

upregulated expression of c-rel at $24 \mathrm{~h}$ found in our study after carrageenin injection could suggest an alternative pathway of activating inflammation in fish. Thus, c-REL homodimers could combinate activating the transcription of inflammation-related genes, since c-REL heterodimers with other NF- $\kappa \mathrm{B}$ components have not been documented (Mulero et al. 2019). In addition, the trigger of a faster inflammatory response than in mammals could also explain that the expression of cytokine genes was not significantly altered in the time tested. Taken together, these results suggest that the activation of these genes might be the first step in the termination of the innate immune response in order to restore homeostasis (Gugasyan et al. 2004).

\section{Conclusion}

These results indicate that the molecules involved in the inflammatory process, especially the proteins involved in the regulation of the inflammatory 
A
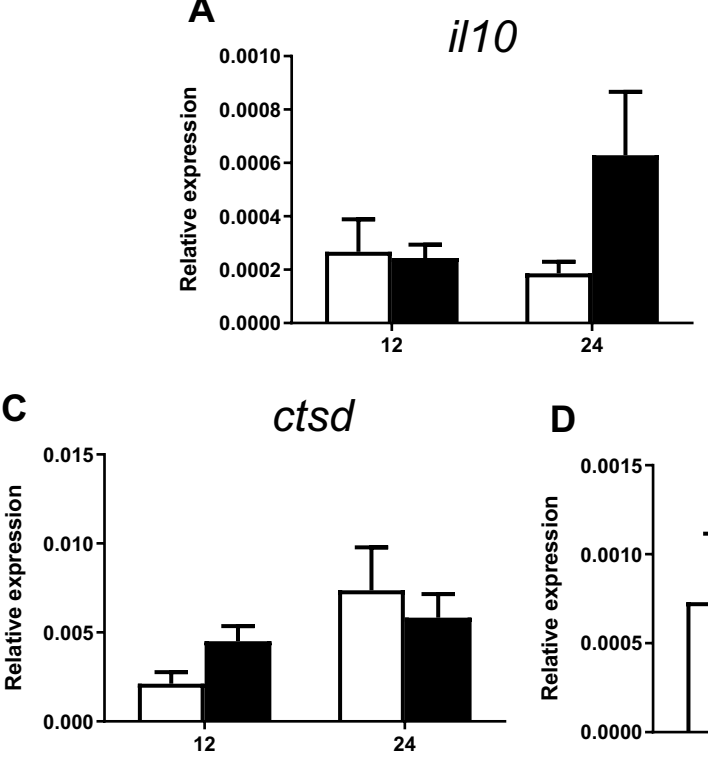

B

D

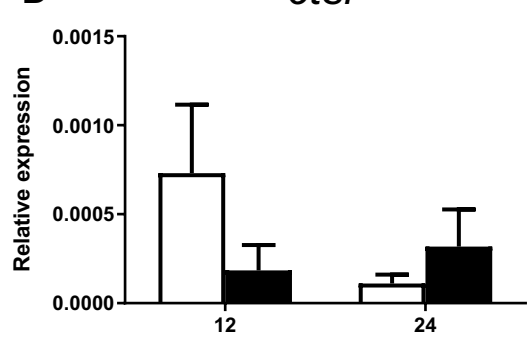

$\operatorname{tg} f b$

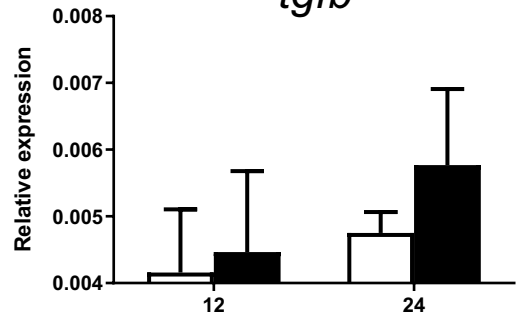

E ctss

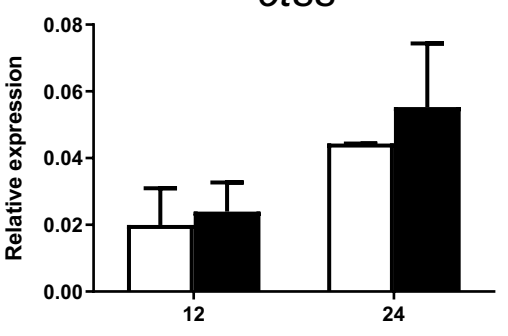

Experimental time (h)

Fig. 7 Relative expression of A $i l 10, \mathbf{B} t g f-b, \mathbf{C} c t s d$, D $c t s l$, and $\mathbf{E}$ ctss in gilthead seabream injected with PBS (control, white bars) and carrageenin (1\%, black bars) analyzed in skin samples collected 12 and $24 \mathrm{~h}$ after injection. The bars repre- sent the mean \pm standard error of the mean $(n=4)$. No significant differences were obtained neither between the carrageenin and control groups nor between the sampling time points (twoway ANOVA; $p<0.05$ )
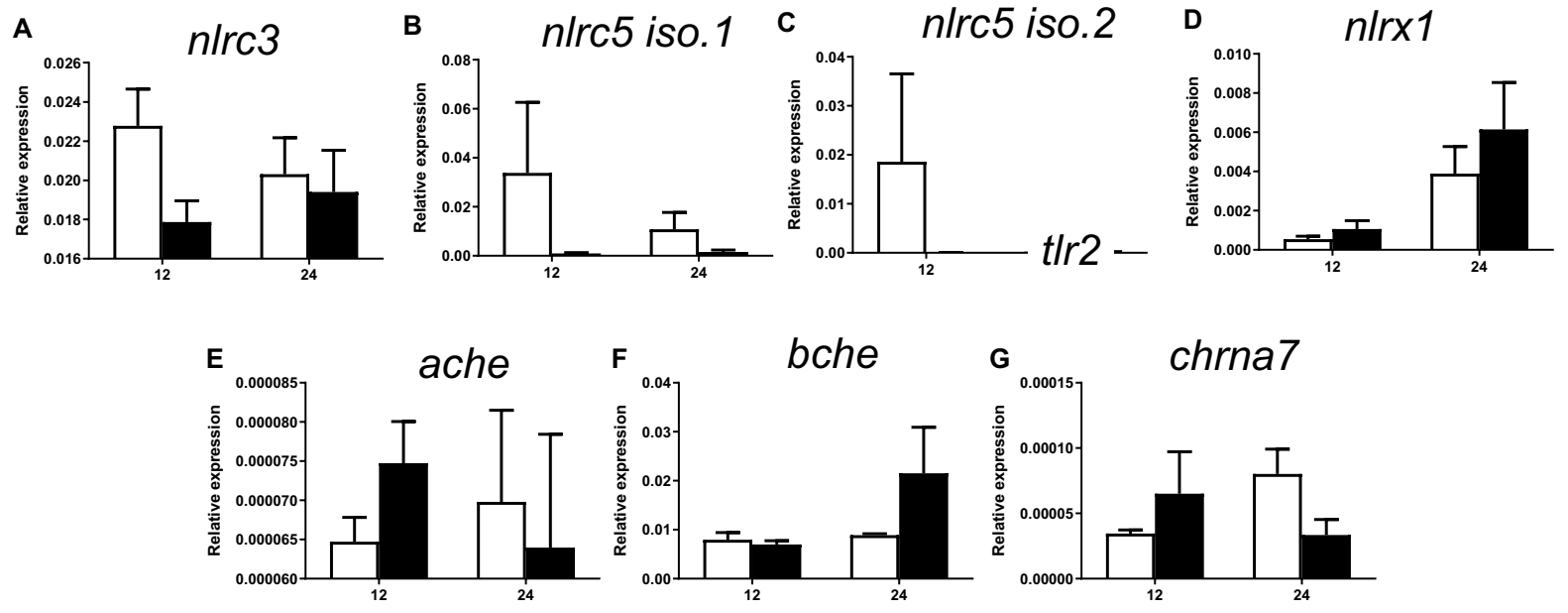

\section{Experimental time (h)}

Fig. 8 Relative expression of A nlrc3, $\mathbf{B}$ isoform 1 of nlrc5, $\mathbf{C}$ isoform 2 of nlrc5, D nlrx 1, E ache, $\mathbf{F}$ bche, and $\mathbf{G}$ chrna 7 in gilthead seabream injected with PBS (control, white bars) and carrageenin (1\%, black bars) analyzed in skin samples collected 12 and $24 \mathrm{~h}$ after injection. The bars represent the mean \pm standard error of the mean $(n=4)$. No significant differences were obtained neither between the carrageenin and control groups nor between the sampling time points (two-way ANOVA; $p<0.05$ ) 


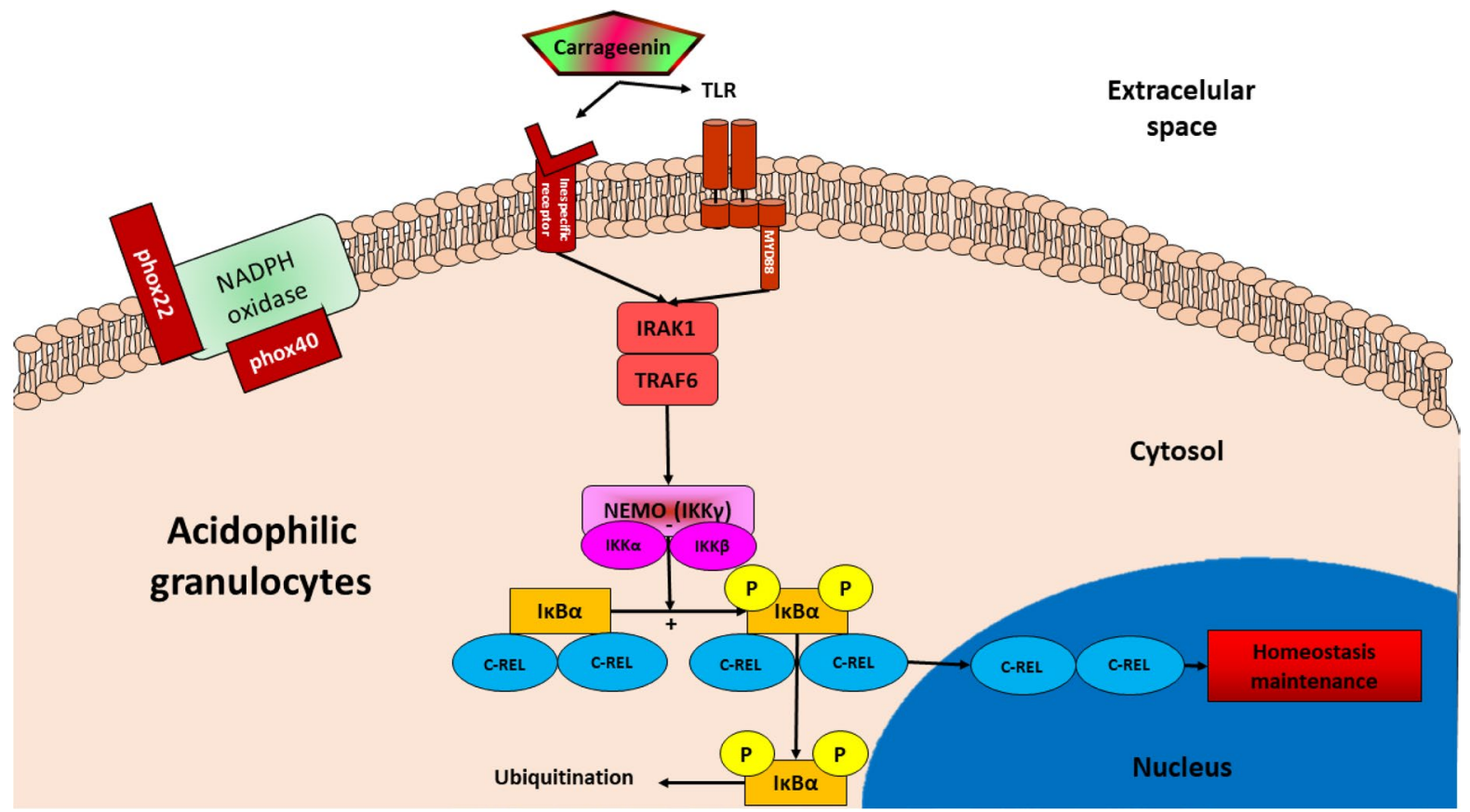

Fig. 9 Proposed schematic inflammatory model of carrageenin-transduction pathway for acidophilic granulocytes in the skin of gilthead seabream. The + and - symbols represent induction and repression interactions, respectively

response, are mostly conserved among fish species, but their main functions can vary depending on the species due to the different orthologues present in each. Furthermore, the inflammation induced by subcutaneous carrageenin injection (at least at the tested dose) in the gilthead seabream abates within hours. The mechanisms necessary to terminate the inflammation response and recover skin homeostasis are activated between 12 and $24 \mathrm{~h}$ after injection. The in silico and gene expression analyses performed in this study might contribute to the identification of the main mechanisms of the acute inflammatory response. Our results have implications not only for applications in the aquaculture sector but also for basic research. Future studies using this characteristic pro-inflammatory mucopolysaccharide are needed to elucidate the complex mechanism of inflammation related to diseases or dietary supplementation in fish.

Author contribution MAE conceptualized the study and MAE and FAG reviewed the research proposal. JCCS and JML conducted the experimentation and sampling. JCCS and JML processed the samples. JCCS and FAG analyzed the data. JCCS and JML wrote the manuscript and MAE and FAG reviewed it. MAE got the financing. All the authors participated in giving feedback on the manuscript. All authors have read and approved the final manuscript.

Funding Open Access funding provided thanks to the CRUE-CSIC agreement with Springer Nature. This work was supported by the Spanish Ministry of Economy and Competitiveness (Grant no. AGL-2017-83370-C3-1-R) co-funded with Fondos Europeos de Desarrollo Regional (FEDER) and Fundación Séneca de la Región de Murcia (Grupo de Excelencia 19883/GERM/15).

Availability of data and material The datasets generated during and/or analyzed during the current study are available from the corresponding author on reasonable request.

Code availability Not applicable.

\section{Declarations}

Ethics approval/declarations The experiment was conducted at the Marine Fish Facilities at the University of Murcia (Spain). All experimental protocols were approved by the Ethical Committee of the University of Murcia (permit number CEEA 357/2017) following the guidelines of European Union for animal handling (2010/63/EU).

Consent to participate All authors consent the participation. 
Consent for publication All authors consent the publication.

Conflict of interest The authors declare no competing interests.

Open Access This article is licensed under a Creative Commons Attribution 4.0 International License, which permits use, sharing, adaptation, distribution and reproduction in any medium or format, as long as you give appropriate credit to the original author(s) and the source, provide a link to the Creative Commons licence, and indicate if changes were made. The images or other third party material in this article are included in the article's Creative Commons licence, unless indicated otherwise in a credit line to the material. If material is not included in the article's Creative Commons licence and your intended use is not permitted by statutory regulation or exceeds the permitted use, you will need to obtain permission directly from the copyright holder. To view a copy of this licence, visit http://creativecommons.org/licenses/by/4.0/.

\section{References}

APROMAR (2019) Aquaculture in Spain. p 91

Balasch JC, Tort L (2019) Netting the stress responses in fish. Front Endocrinol (Lausanne) 10:1-12. https://doi.org/10. 3389/fendo.2019.00062

Balcázar JL, de Blas I, Ruiz-Zarzuela I, Cunningham D, Vendrell D, Múzquiz JL (2006) The role of probiotics in aquaculture. Vet Microbiol 114:173-186. https://doi.org/10. 1016/j.vetmic.2006.01.009

Belambri SA, Rolas L, Raad H, Hurtado-Nedelec M, Dang PM, El-Benna J (2018) NADPH oxidase activation in neutrophils: role of the phosphorylation of its subunits. Eur J Clin Invest 48:1-9. https://doi.org/10.1111/eci.12951

Bhattacharyya S, Dudeja PK, Tobacman JK (2008a) Carrageenan-induced NFKB activation depends on distinct pathways mediated by reactive oxygen species and Hsp27 or by Bcl10. Biochim Biophys Acta 1780:973-982. https://doi.org/10.1038/jid.2014.371

Bhattacharyya S, Gill R, Chen ML, Zhang F, Linhardt RJ, Dudeja PK, Tobacman JK (2008b) Toll-like receptor 4 mediates induction of the Bcl10-NFKB-interleukin-8 inflammatory pathway by carrageenan in human intestinal epithelial cells. J Biol Chem 283:10550-10558. https:// doi.org/10.1074/jbc.M708833200

Bhattacharyyaa S, Liu H, Zhang Z, Jam M, Dudeja PK, Michel G, Linhardt RJ, Tobacman JK (2010) Carrageenaninduced innate immune response is modified by enzymes that hydrolyze distinct galactosidic bonds. J Nutr Biochem 21:906-913. https://doi.org/10.1038/jid.2014.371

Bjorne J, Salakoski T (2019) Biomedical event extraction using convolutional neural networks and dependency parsing. Proceedings of the BioNLP workshop, pp 98-108

Byadgi O, Chen YC, Maekawa S, Wang PC, Chen SC (2018) Immune-related functional differential gene expression in koi carp (Cyprinus carpio) after challenge with
Aeromonas sobria. Int J Mol Sci 19:1-15. https://doi.org/ 10.3390/ijms 19072107

Calder PC, Ahluwalia N, Albers R, Bosco N, Bourdet-Sicard R, Haller D, Holgate ST, Jönsson LS, Latulippe ME, Mar$\cos$ A, Moreines J, Mrini C, Müller M, Pawelec G, Van Neerven RJJ, Watzl B, Zhao J (2013) A consideration of biomarkers to be used for evaluation of inflammation in human nutritional studies. Br J Nutr 109.https://doi.org/ 10.1017/S0007114512005119

Campos-Sánchez JC, Esteban MÁ (2021) Review of inflammation in fish and value of the zebrafish model. J Fish Dis 44:123-139. https://doi.org/10.1111/jfd.13310

Chen GY, Nuñez G (2010) Sterile inflammation: sensing and reacting to damage. Nat Rev Immunol 10:826-837. https://doi.org/10.1038/nri2873

Cheng AC, Tu CW, Chen YY, Nan FH, Chen JC (2007) The immunostimulatory effects of sodium alginate and iotacarrageenan on orange-spotted grouper Epinephelus coicoides and its resistance against Vibrio alginolyticus. Fish Shellfish Immunol 22:197-205. https://doi.org/10.1016/j. fsi.2006.04.009

Chomczynski P (1993) A reagent for the single-step simultaneous isolation of RNA, DNA and proteins from cell and tissue samples. Biotechniques 15:532-537

Conus S, Simon HU (2008) Cathepsins: key modulators of cell death and inflammatory responses. Biochem Pharmacol 76:1374-1382. https://doi.org/10.1016/j.bcp.2008.07.041

Conus S, Perozzo R, Reinheckel T, Peters C, Scapozza L, Yousefi S, Simon HU (2008) Caspase- 8 is activated by cathepsin D initiating neutrophil apoptosis during the resolution of inflammation. J Exp Med 205:685-698. https:// doi.org/10.1084/jem.20072152

Cordero H, Brinchmann MF, Cuesta A, Meseguer J, and. Esteban MA, (2015) Skin mucus proteome map of European sea bass (Dicentrarchus labrax). Proteomics 15:40074020. https://doi.org/10.1002/pmic.201500120

Cordero H, Brinchmann MF, Cuesta A, Esteban MA (2017) Chronic wounds alter the proteome profile in skin mucus of farmed gilthead seabream. BMC Genomics 18:1-14. https://doi.org/10.1186/s12864-017-4349-3

Cui J, Zhu L, Xia X, Wang HY, Legras X, Jun H, Ji J, Shen P, Zheng S, Chen ZJ, Wang RF (2010) NLRC5 negatively regulates the NF- $\mathrm{KB}$ and type I interferon signaling pathways and antiviral immunity. Cell 141:483-496. https:// doi.org/10.1016/j.cell.2010.03.040.NLRC5

Delamare-Deboutteville J, Wood D, Barnes AC (2006) Response and function of cutaneous mucosal and serum antibodies in barramundi (Lates calcarifer) acclimated in seawater and freshwater. Fish Shellfish Immunol 21:92101. https://doi.org/10.1016/j.fsi.2005.10.005

Dijkstra JM, Grimholt U, Leong J, Koop BF, Hashimoto K (2013) Comprehensive analysis of MHC class II genes in teleost fish genomes reveals dispensability of the peptide-loading DM system in a large part of vertebrates. BMC Evol Biol 13:1-14. https://doi.org/10.1186/ 1471-2148-13-260

Esteban MA (2012) An overview of the immunological defenses in fish skin. ISRN Immunol 2012:1-29. https:// doi.org/10.5402/2012/853470

Etemadi N, Chopin M, Anderton H, Tanzer MC, Rickard JA, Abeysekera W, Hall C, Spall SK, Wang B, Xiong Y, Hla 
T, Pitson ST, Bonder CS, Wong WWL, Ernst M, Smyth GK, Vaux DL, Nutt SL, Nachbur U, Silke J (2015) TRAF2 regulates TNF and NF- $\kappa B$ signalling to suppress apoptosis and skin inflammation independently of sphingosine kinase. Elife 4:1-27. https://doi.org/10.7554/eLife. 10592

Fujiki K, Matsuyama H, Yano T (1994) Protective effect of sodium alginates against bacterial infection in common carp, Cyprinus carpio L. J Fish Dis 17:349-355. https:// doi.org/10.1111/j.1365-2761.1994.tb00230.x

Fujiki K, Shin D, Nakao M, Yano T (1997) Effects of $\kappa$-carrageenan on the non-specific of carp Cyprinus carpio. Fish Sci 63:934-938. https://doi.org/10.2331/fishsci. 63.934

Gilson AI, Marshall-Christensen A, Choi JM, Shakhnovich EI (2017) The role of evolutionary selection in the dynamics of protein structure evolution. Biophys J 112:1350-1365. https://doi.org/10.1016/j.bpj.2017.02.029

Grayfer L, Hanington PC, Belosevic M (2009) Macrophage colony-stimulating factor (CSF-1) induces pro-inflammatory gene expression and enhances antimicrobial responses of goldfish (Carassius auratus L.) macrophages. Fish Shellfish Immunol 26:406-413. https://doi. org/10.1016/j.fsi.2008.12.001

Grayfer L, Kerimoglu B, Yaparla A, Hodgkinson JW, Xie J, Belosevic M (2018) Mechanisms of fish macrophage antimicrobial immunity. Front Immunol 9.https://doi.org/10. 3389/fimmu.2018.01105

Gugasyan R, Voss A, Varigos G, Thomas T, Grumont RJ, Kaur P, Grigoriadis G, Gerondakis S (2004) The transcription factors c-rel and RelA control epidermal development and homeostasis in embryonic and adult skin via distinct mechanisms. Mol Cell Biol 24:5733-5745. https://doi. org/10.1128/mcb.24.13.5733-5745.2004

Hanington PC, Tam J, Katzenback BA, Hitchen SJ, Barreda DR, Belosevic M (2009) Development of macrophages of cyprinid fish. Dev Comp Immunol 33:411-429. https://doi.org/10.1016/j.dci.2008.11.004

Hawiger J, Zienkiewicz J (2019) Decoding inflammation, its causes, genomic responses, and emerging countermeasures. Scand J Immunol 90:1-32. https://doi.org/10.1111/ sji. 12812

Henson PM (2005) Dampening inflammation nature 06. Nat Immunol 6:1179-1181. https://doi.org/10.1038/ ni1205-1179

Hinz M, Stilmann M, Arslan SÇ, Khanna KK, Dittmar G, Scheidereit C (2010) A cytoplasmic ATM-TRAF6cIAP1 module links nuclear DNA damage signaling to ubiquitin-mediated NF- $\kappa$ B activation. Mol Cell 40:6374. https://doi.org/10.1016/j.molcel.2010.09.008

Huang SY, Feng CW, Hung HC, Chakraborty C, Chen CH, Chen WF, Jean YH, Wang HMD, Sung HS, Sun YM, Wu CY, Liu W, Hsiao CD, Wen ZH (2014) A novel zebrafish model to provide mechanistic insights into the inflammatory events in carrageenan-induced abdominal edema. PLoS ONE 9.https://doi.org/10.1371/journal. pone. 0104414

Kaneda N, Kawauchi H, Mogi G (1991) Role of phagocytes in antimicrobial defence of the middle ear. Auris Nasus Larynx 18:331-342. https://doi.org/10.1016/S03858146(12)80226-4
Kawahara T, Lambeth JD (2007) Molecular evolution of Phox-related regulatory subunits for NADPH oxidase enzymes. BMC Evol Biol 7:1-29. https://doi.org/10. 1186/1471-2148-7-178

Kolaczkowska E, Kubes P (2013) Neutrophil recruitment and function in health and inflammation. Nat Rev Immunol 13:159-175. https://doi.org/10.1038/nri3399

Konaté MM, Plata G, Park J, Usmanova DR, Wang HH, Vitkup D (2017) Molecular function limits divergent protein evolution on planetary timescales. bioRxiv 1-21. https://doi.org/10.1101/198663

Kummer KK, Kalpachidou T, Kress M, Langeslag M (2018) Signatures of altered gene expression in dorsal root ganglia of a Fabry disease mouse model. Front Mol Neurosci 10:1-16. https://doi.org/10.3389/fnmol.2017.00449

Levy L (1969) Carrageenan paw edema in the mouse. Life Sci 8:601-606. https://doi.org/10.1016/0024-3205(69) 90021-6

Li Q, Ao J, Mu Y, Yang Z, Li T, Zhang X, Chen X (2015) Cathepsin S, but not cathepsin L, participates in the MHC class II-associated invariant chain processing in large yellow croaker (Larimichthys crocea). Fish Shellfish Immunol 47:743-750. https://doi.org/10.1016/j.fsi. 2015.10.009

Linares JF, Duran A, Yajima T, Pasparakis M, Moscat J, Diaz-Meco MT (2013) K63 polyubiquitination and activation of mTOR by the p62-TRAF6 complex in nutrientactivated cells. Mol Cell 51:283-296. https://doi.org/10. 1016/j.molcel.2013.06.020

Liu H, Beck TN, Golemis EA, Serebriiskii IG (2014) Integrating in silico resources to map a signaling network. In: Ochs M (ed) Gene Function Analysis. Methods Mol Biol (Methods and Protocols), vol 1101. Humana Press, Totowa. https://doi.org/10.1007/978-1-62703-721-1_11

Livak KJ, Schmittgen TD (2001) Analysis of relative gene expression data using real-time quantitative PCR and the 2- $\Delta \Delta \mathrm{CT}$ method. Methods 25:402-408. https://doi. org/10.1006/meth.2001.1262

Makrodimitris S, Reinders M, van Ham R (2020) A thorough analysis of the contribution of experimental, derived and sequence-based predicted protein-protein interactions for functional annotation of proteins. PLoS ONE 15:1-18. https://doi.org/10.1371/journal.pone.0242723

Martins ML, de Moraes FR, Fujimoto RY, Onaka EM, Bozzo FR, de Moraes JRE (2006) Carrageenin induced inflammation Piaractus mesopotamicus (Osteichthyes : Characidae) culured in Brazil. Bol Inst Pesca 32:31-39 (https://www.pesca.sp.gov.br/boletim/index.php/bip/ article/view/713)

Matsuzawa A, Saegusa K, Noguchi T, Sadamitsu C, Nishitoh H, Nagai S, Koyasu S, Matsumoto K, Takeda K, Ichijo $H$ (2005) ROS-dependent activation of the TRAF6ASK1-p38 pathway is selectively required for TLR4mediated innate immunity. Nat Immunol 6:587-592. https://doi.org/10.1038/ni1200

Matushima E, Mariano M (1996) Kinetics of the inflammatory reaction induced by carrageenin in the swimbladder of Oreochromis niloticus (Nile tilapia). Braz J Vet Res Anim Sci 33:5-10. https://doi.org/10.11606/issn.23183659.v33i1p5-10 
Medzhitov R (2008) Origin and physiological roles of inflammation. Nature 454:428-435. https://doi.org/10. 1038/nature07201

Meseguer J, López-Ruiz A, Esteban MA (1994) Cytochemical characterization of leucocytes from the seawater teleost, gilthead seabream (Sparus aurata L.). Histochemistry 102:37-44. https://doi.org/10.1007/BF00271047

Meseguer J, Lopez Ruiz A, Garcia Ayala A (1995) Reticuloendothelial stroma of the head-kidney from the seawater teleost gilthead seabream (Sparus aurata L.): an ultrastructural and cytochemical study. Anat Rec 241:303309. https://doi.org/10.1002/ar.1092410303

Mitsuyama M, Nomoto K, Takeya K (1982) Direct correlation between delayed footpad reaction and resistance to local bacterial infection. Infect Immun 36:72-79. https://doi.org/10.1128/iai.36.1.72-79.1982

Morris CJ (2003) Carrageenan-induced paw edema in the rat and mouse. Methods Mol Biol 225:115-121. https://doi. org/10.1385/1-59259-374-7:115

Moscat J, Diaz-meco MT (2016) Amino acid activation of mTORC1 by a PB1-domain-driven kinase complex cascade. Cell Rep 12:1339-1352. https://doi.org/10.1016/j. celrep.2015.07.045

Mulero MC, Wang VYF, Huxford T, Ghosh G (2019) Genome reading by the NF- $\mathrm{KB}$ transcription factors. Nucleic Acids Res 47:9967-9989. https://doi.org/10. 1093/nar/gkz739

Napetschnig J, Wu H (2013) Molecular basis of NF-кB signaling. Annu Rev Biophys:443-468.https://doi.org/10.1146/ annurev-biophys-083012-130338

Nathan C (2002) Points of control in inflammation. Nature 420:846-852. https://doi.org/10.1038/nature01320

Nathan C (2006) Neutrophils and immunity: challenges and opportunities. Nat Rev Immunol 6:173-182. https://doi. org/10.1038/nri1785

Nathan C, Ding A (2010) Nonresolving inflammation. Cell 140:871-882. https://doi.org/10.1016/j.cell.2010.02.029

Necas J, Bartosikova L (2013) Carrageenan: a review. Vet Med (Praha) 58:187-205. https://doi.org/10.17221/ 6758-VETMED

Nguyen-Chi M, Laplace-Builhe B, Travnickova J, LuzCrawford P, Tejedor G, Phan QT, Duroux-Richard I, Levraud JP, Kissa K, Lutfalla G, Jorgensen C, Djouad F (2015) Identification of polarized macrophage subsets in zebrafish. Elife 4:1-14. https://doi.org/10.7554/eLife. 07288

Pareek CS, Smoczynski R, Tretyn A (2011) Sequencing technologies and genome sequencing. J Appl Genet 52:413435. https://doi.org/10.1007/s13353-011-0057-x

Phelps HA, Neely MN (2007) SalY of the Streptococcus pyogenes lantibiotic locus is required for full virulence and intracellular survival in macrophages. Infect Immun 75:4541-4551. https://doi.org/10.1128/IAI.00518-07

Postlethwait JH, Woods IG, Ngo-Hazelett P et al (2000) Zebrafish comparative genomics and the origins of vertebrate chromosomes. Genome Res 10:1890-1902. https://doi.org/10.1101/gr.164800

Reactome (2021) TNF signaling. Available online: http:// www.reactome.org/content/. Accessed 3 Mar 2021

Rezaeian AH, Li CF, Wu CY, Zhang X, Delacerda J, You MJ, Han F, Cai Z, Jeong YS, Jin G, Phan L, Chou
PC, Lee MH, Hung MC, Sarbassov D, Lin HK (2017) A hypoxia-responsive TRAF6-ATM-H2AX signalling axis promotes HIF1 $\alpha$ activation, tumorigenesis and metastasis. Nat Cell Biol 19(1):38-51. https://doi. org/10.1038/ncb3445

Ribas JLC, Zampronio AR, Silva de Assis HC (2016) Effects of trophic exposure to diclofenac and dexamethasone on hematological parameters and immune response in freshwater fish. Environ Toxicol Chem 35:975-982. https://doi.org/10.1002/etc.3240

Roca FJ, Sepulcre MP, López-Castejón G, Meseguer J, Mulero V (2006) The colony-stimulating factor-1 receptor is a specific marker of macrophages from the bony fish gilthead seabream. Mol Immunol 43:1418-1423. https://doi.org/10.1016/j.molimm.2005.07.028

Romano JD, Tatonetti NP (2019) Informatics and computational methods in natural product drug discovery: a review and perspectives. Front Genet 10:1-16. https:// doi.org/10.3389/fgene.2019.00368

Sarropoulou E, Franch R, Louro B, Power DM, Bargelloni L, Magoulas A, Senger F, Tsalavouta M, Patarnello T, Galibert F, Kotoulas G, Geisler R (2007) A gene-based radiation hybrid map of the gilthead sea bream Sparus aurata refines and exploits conserved synteny with Tetraodon nigroviridis. BMC Genomics 8:1-14. https:// doi.org/10.1186/1471-2164-8-44

Savan R, Sakai M (2006) Genomics of fish cytokines. Comp Biochem Physiol D Genomics Proteomics 1:89-101. https://doi.org/10.1016/j.cbd.2005.08.005

Schneider M, Zimmermann AG, Roberts RA, Zhang L, Swanson KV, Wen H, Davis BK, Allen IC, Holl EK, Ye Z, Rahman AH, Conti BJ, Eitas TK, Koller BH, Ting JP (2012) The innate immune sensor NLRC3 attenuates toll-like receptor signaling via modification of the signaling adaptor TRAF6 and transcription factor NF- $\mathrm{KB}$. Nat Immunol 13:823. https://doi.org/10.1038/ni.2378

Secombes CJ, Wang T, Bird S (2011) The interleukins of fish. Dev Comp Immunol 35:1336-1345. https://doi.org/10. 1016/j.dci.2011.05.001

Sepulcre M, Pelegrín P, Mulero V, Meseguer J (2002) Characterisation of gilthead seabream acidophilic granulocytes by a monoclonal antibody unequivocally points to their involvement in fish phagocytic response. Cell Tissue Res 308:97-102. https://doi.org/10.1007/s00441-002-0531-1

Serhan CN, Brain SD, Buckley CD et al (2011) Resolution of inflammation: state of the art, definitions and terms. FASEB J 21:325-332. https://doi.org/10.1096/fj.06-7227r ev

Silva-Marrero JI, Sáez A, Caballero-Solares A, Viegas I, Almajano MP, Fernández F, Baanante IV, Metón I (2017) A transcriptomic approach to study the effect of long-term starvation and diet composition on the expression of mitochondrial oxidative phosphorylation genes in gilthead sea bream (Sparus aurata). BMC Genomics 18:1-16. https:// doi.org/10.1186/s12864-017-4148-x

Szklarczyk D, Gable AL, Lyon D, Junge A, Wyder S, HuertaCepas J, Simonovic M, Doncheva NT, Morris JH, Bork P, Jensen LJ, Mering CV (2019) STRING v11: proteinprotein association networks with increased coverage, supporting functional discovery in genome-wide 
experimental datasets. Nucleic Acids Res 47:D607-D613. https://doi.org/10.1093/nar/gky1131

Tan P, Li X, Xiang X, Dong X, Li S, Mai K, Ai Q (2019) Adipose tissue contributes to hepatic pro-inflammatory response when dietary fish oil is replaced by vegetable oil in large yellow croaker (Larimichthys crocea): an ex vivo study. Fish Shellfish Immunol 84:955-961. https://doi.org/ 10.1016/j.fsi.2018.10.086

Tang HW, Liao HM, Peng WH, Lin HR, Chen CH, Chen GC (2013) Atg9 interacts with dTRAF2/TRAF6 to regulate oxidative stress-induced JNK activation and autophagy induction. Dev Cell 27:489-503. https://doi.org/10.1016/j. devcel.2013.10.017

Timur M, Roberts RJ, McQueen A (1977) Carrageenin granuloma in the plaice (Pleuronectes platessa); a histopathological study of chronic inflammation in a teleost fish. J Comp Pathol 87:89-96. https://doi.org/10.1016/00219975(77)90083-4

Tsakogiannis A, Manousaki T, Lagnel J, Papanikolaou N, Papandroulakis N, Mylonas CC, Tsigenopoulos CS (2019) The gene toolkit implicated in functional sex in Sparidae hermaphrodites: inferences from comparative transcriptomics. Front Genet 10.https://doi.org/10.3389/fgene. 2018.00749

Tzeng HE, Tsai CH, Chang ZL, Su CM, Wang SW, Hwang WL, Tang CH (2013) Interleukin-6 induces vascular endothelial growth factor expression and promotes angiogenesis through apoptosis signal-regulating kinase 1 in human osteosarcoma. Biochem Pharmacol 85:531-540. https://doi.org/10.1016/j.bcp.2012.11.021

Wang T, Secombes CJ (2013) The cytokine networks of adaptive immunity in fish. Fish Shellfish Immunol 35:17031718. https://doi.org/10.1016/j.fsi.2013.08.030
Wang P, Wang J, Su YQ, Mao Y, Zhang JS, Wu CW, Ke QZ, Han KH, Zheng WQ, Xu ND (2016) Transcriptome analysis of the Larimichthys crocea liver in response to Cryptocaryon irritans. Fish Shellfish Immunol 48:1-11. https:// doi.org/10.1016/j.fsi.2015.11.011

Winter CA, Risley EA, Nuss GW (1962) Carrageenin-induced edema in hind paw of the rat as an assay for antiinflammatory drugs. Proc Soc Exp Biol Med 111:544-547. https:// doi.org/10.3181/00379727-111-27849

Xia X, Cui J, Wang HY, Zhu L, Matsueda S, Wang Q, Yang X, Hong J, Songyang Z, Chen ZJ, Wang RF (2011) NLRX1 negatively regulates TLR-induced NF-kB signaling by targeting TRAF6 and IKK. Inmunity 34:843-853. https:// doi.org/10.1016/j.immuni.2011.02.022.NLRX1

Yamaguchi, Dijkstra (2019) Major histocompatibility complex (MHC) genes and disease resistance in fish. Cells 8:378. https://doi.org/10.3390/cells8040378

Zhang X, Li CF, Zhang L et al (2016) TRAF6 restricts p53 mitochondrial translocation, apoptosis, and tumor suppression. Mol Cell 64:803-814. https://doi.org/10.1016/j. molcel.2016.10.002

Zila ID, Kopincova MJ, Kolomaznik M, Javorka M (2017) Vagal-immune interactions involved in cholinergic antiinflammatory pathway. Physiol Res 66:S139-S145. https://doi.org/10.33549/physiolres.933671

Publisher's note Springer Nature remains neutral with regard to jurisdictional claims in published maps and institutional affiliations. 